\title{
Alzheimer's Disease: A Pathogenetic Autoimmune Disorder Caused by Herpes Simplex in a Gene-Dependent Manner
}

\author{
C. J. Carter \\ Polygenic Pathways, Flat 4, 20 Upper Maze Hill, Saint Leonard's on Sea, East Sussex TN38 OLG, UK \\ Correspondence should be addressed to C. J. Carter, chris_car@yahoo.com
}

Received 23 July 2010; Revised 27 September 2010; Accepted 22 October 2010

Academic Editor: Paula Moreira

Copyright $\odot 2010$ C. J. Carter. This is an open access article distributed under the Creative Commons Attribution License, which permits unrestricted use, distribution, and reproduction in any medium, provided the original work is properly cited.

Herpes simplex is implicated in Alzheimer's disease and viral infection produces Alzheimer's disease like pathology in mice. The virus expresses proteins containing short contiguous amino acid stretches (5-9aa "vatches" = viralmatches) homologous to APOE4, clusterin, PICALM, and complement receptor 1, and to over 100 other gene products relevant to Alzheimer's disease, which are also homologous to proteins expressed by other pathogens implicated in Alzheimer's disease. Such homology, reiterated at the DNA level, suggests that gene association studies have been tracking infection, as well as identifying key genes, demonstrating a role for pathogens as causative agents. Vatches may interfere with the function of their human counterparts, acting as dummy ligands, decoy receptors, or via interactome interference. They are often immunogenic, and antibodies generated in response to infection may target their human counterparts, producing protein knockdown, or generating autoimmune responses that may kill the neurones in which the human homologue resides, a scenario supported by immune activation in Alzheimer's disease. These data may classify Alzheimer's disease as an autoimmune disorder created by pathogen mimicry of key Alzheimer's diseaserelated proteins. It may well be prevented by vaccination and regular pathogen detection and elimination, and perhaps stemmed by immunosuppression or antibody adsorption-related therapies.

\section{Introduction}

Herpes simplex infection (HSV-1) has been shown to be a risk factor in Alzheimer's disease; acting in synergy with possession of the APOE4 allele HSV-1 infection in mice or neuroblastoma cells increases beta-amyloid deposition and phosphorylation of the microtubule protein tau [15]. Viral infection in mice also results in hippocampal and entorhinal cortex neuronal degeneration, brain shrinkage, and memory loss, all as found in Alzheimer's disease [6]. A recent study has also shown that anti-HSV-1 immunoglobulin $\mathrm{M}$ seropositivity, a marker of primary viral infection or reactivation, in a cohort of healthy patients, was significantly associated with the subsequent development of Alzheimer's disease. Anti-HSV-1 IgG, a marker of lifelong infection, showed no association with subsequent Alzheimer's disease development [7]. All of these factors support a viral influence on the development of Alzheimer's disease. As shown below, proteins expressed by HSV-1 are homologous to all of the protein products of the major susceptibility gene in
Alzheimer's disease (APOE, clusterin, complement receptor 1 , and PICALM) as well as to APP and tau and over 100 others implicated in genetic association studies. This suggests that Alzheimer's disease is a "pathogenetic" disorder caused by HSV-1 (and other infections) that mimic these key susceptibility targets.

\section{Methods}

The Human herpesvirus 1 genome (NC_001798) was screened against the human proteome using the NCBI BLAST server with and without the Entrez Query filters ("Alzheimer" or "cholesterol") [8]. Each BLAST re-turns a large list of human proteins, many of which display homology to several different HSV-1 proteins. A Tag cloud generator was used to quantify these different interactions http://www.tagcloud-generator.com/index.php. This generates tags whose font size is proportional to the number of viral protein hits per human protein. The tag size scale was set from 1 to 20. Antigenicity (B cell epitope 
TABLE 1: The antigenicity index (B cell epitope) for single amino acids defined by the BepiPred server. The top 6 scoring amino acids are highlighted in grey in the various tables.

\begin{tabular}{lcc}
\hline Symbol & Amino acid & $\begin{array}{c}\text { B-epitope } \\
\text { antigenicity }\end{array}$ \\
\hline P & Proline & 0.145 \\
G & Glycine & 0.035 \\
D & Aspartate & 0.018 \\
E & Glutamate & 0.003 \\
S & Serine & -0.008 \\
T & Threonine & -0.011 \\
Q & Glutamine & -0.012 \\
N & Asparagine & -0.013 \\
A & Alanine & -0.024 \\
W & Tryptophan & -0.025 \\
K & Lysine & -0.031 \\
R & Arginine & -0.062 \\
H & Histidine & -0.071 \\
V & Valine & -0.112 \\
F & Phenylalanine & -0.138 \\
I & Isoleucine & -0.138 \\
M & Methionine & -0.138 \\
C & Cysteine & -0.175 \\
\hline
\end{tabular}

prediction) was predicted using the BepiPred server [9] at http://www.cbs.dtu.dk/services/BepiPred/ and T cell epitopes predicted using the Immune epitope database resource at http://tools.immuneepitope.org/main/html/tcell_tools.html [10]. The immunogenicity index for individual amino acids is shown in Table 1. References for genetic association studies can be found at http://www.polygenicpathways.co. uk/alzpolys.htm. References for herpes simplex host viral interactions can be found in a database at http://www.polygenicpathways.co.uk/herpeshost.html. Protein kinases phosphorylating the microtubule protein tau were identified from the Kinasource database at http://www.kinasource.co.uk/ Database/welcomePage.php and from the material available at the ENTREZ gene interaction section for tau (MAPT).

Because of the large volume of data generated by the BLASTs, raw BLAST data have been made available at http:// www.polygenicpathways.co.uk/Alzheimer.htm. This survey is restricted to the herpes simplex virus, HSV-1, but similar data were obtained for other viral or pathogen species implicated in Alzheimer's disease, where similar conclusions apply. These BLAST files and a summary of the results are available on the PolygenicPathways website at http://www .polygenicpathways.co.uk/BLASTS.htm.

\section{Results}

The results of the HSV-1 BLASTS, sized according to the number of viral hits per protein, using the filter "Alzheimer," are shown in Table 2. Over a hundred human gene products, including all of the major Alzheimer's disease susceptibility gene products (APOE4, clusterin, complement receptor 1, and PICALM) and most of many other diverse genes that have been implicated in Alzheimer's disease in genetic association studies contain intraprotein sequences that are identical to those within herpes simplex viral proteins. The alignment with complement receptor 1 (CR1) has functional consequences, as glycoprotein $\mathrm{C}$ of the virus acts as a CR1 mimic, binding to other complement components (C3 and its derivatives) blocking the complement cascades and preventing formation of the membrane attack complex [12, 13]. This nicely illustrates one of the functional consequences of this type of mimicry.

The type of viral homology for various different protein classes is shown in Table 3. These classes include products involved in APP signalling and processing (BACE1 and 2 and gamma-secretase components), cholesterol and lipoprotein function, tau function, inflammation, and oxidative stress, all of which are key processes disrupted in the Alzheimer's disease brain.

Using the filter "cholesterol," a number of cholesterol and lipoprotein-related proteins again contain numerous sequences corresponding to those found in herpes viral proteins. This group of proteins play an important role in Alzheimer's disease pathophysiology [14-17].

The unfiltered BLAST returns the human proteins with the greatest homology to viral proteins and showed that herpes simplex viral proteins are highly homologous to a series of family members of diverse protein kinases. Several of these are known to phosphorylate the microtubule protein tau, an effect that is observed following HSV-1 infection [5]. The homology is such as to suggest that such phosphorylation may be accomplished by the viral proteins themselves, as well as by human protein kinases (Table 4).

This type of mimicry is by no means restricted to the herpes simplex virus as APOE4, clusterin, complement receptor 1, and PICALM are homologous to proteins from a diverse array of phages and viruses including phages that affect commensal bacteria, the influenza virus, and the HHV6 virus which has a seroprevalence approaching 100\% [18] (Table 5). Because of the universality of the phenomenon of viral matches within the human proteome, most proteins will be homologous to proteins from specific subsets of viruses. Viruses and other pathogens expressing proteins with homology to key susceptibility gene products might however be considered as important potential environmental risk factors. For the major Alzheimer's disease gene candidates, several herpes species other than HSV-1 (HSV-2, 3, 6, $6 \mathrm{~B}$, and 8) fall into this category (Table 5).

The tables in supplementary data on the website http:// www.polygenicpathways.co.uk/alzheimer.htm show that numerous Alzheimer's disease susceptibility gene products are also homologous to proteins expressed by other pathogen risk factors in Alzheimer's disease, including Chlamydia pneumonia, which has recently been detected in the Alzheimer's disease brain [19].

Cryptococcus neoformans, Helicobacter pylori, Porphyromonas gingivalis (one cause of the gum disease that is a risk factor in Alzheimer's disease [20]), Borrelia Burgdorferi, 
TABle 2: Human proteins with homology to HSV-1 proteins: The size of symbol (HUGO Nomenclature approved gene symbols) is proportional to the number of viral proteins displaying homology to the gene product. Filter "Alzheimer": all of the genes encoding for these proteins with the exception of those with the strikethrough have been implicated in Alzheimer's disease in genetic association studies. Filter "cholesterol": genes encoding for proteins products in dashed boxes have been implicated in Alzheimer's disease in genetic association studies. No Filter: HSV-1 proteins are most homologous to diverse families of kinases: Those boxed have been shown to phosphorylate the microtubule protein tau (Data from Kinasource and from NCBI Interactions section for the MAPT gene (tau)).

\begin{tabular}{|c|c|}
\hline BLAST filter & Gene products with homology to HSV-1 proteins \\
\hline \multirow{11}{*}{$\begin{array}{l}\text { HSV-1 Filter } \\
\text { "Alzheimer" }\end{array}$} & Major genes APOE4 cLU CR1 GR1L APP related APLP1 APP \\
\hline & APPBA2 APBB1 APBB2 APBB3 COL25A1 MAPK8IP1 IDE SERPINA3 \\
\hline & SNCA Secretase related BACE1 BACE2 NCSTN PEN2 \\
\hline & PSEN1 PSEN2 tau related MAPT \\
\hline & related A2M CH25H нmGсR LRP1 OLR1 SORCS1sORCs3 SORL1 \\
\hline & Channels ${ }_{\text {CACnB2 }}$ OXIDATIVE STRESS ATP6 COX2 coх3 CYTB \\
\hline & HMOX1 NADH4Ł ND1 No4 Noo1 Cytokine/immune CX3CL1 мICB \\
\hline & MISCELLANEOUS ALDH18A1 aTp2C1 BLMH \\
\hline & CTNNA3 дLd DKK1 DLST DNTT DPYSL2 ECE1 ENTPD2 FAM3A \\
\hline & 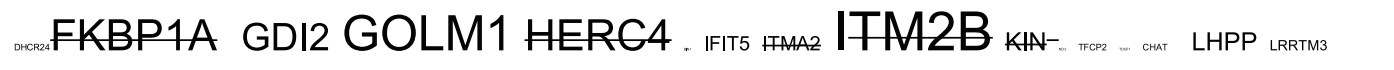 \\
\hline & 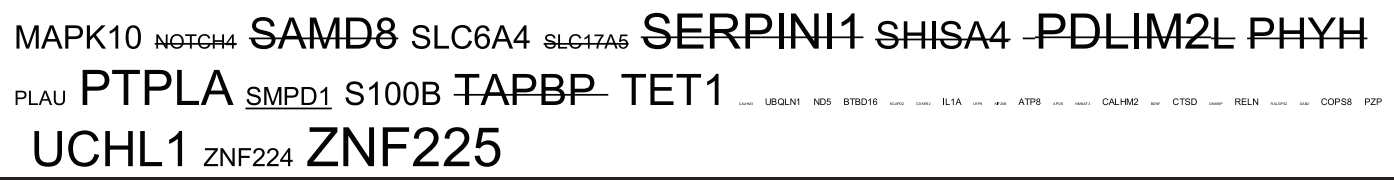 \\
\hline \multirow{17}{*}{$\begin{array}{l}\text { Hsv-1 Query } \\
\text { Cholesterol }\end{array}$} & ATP cassette ${ }_{A B C A 3}$ ABCA6 $A B C A 9$ ABCA10 ABCD2 ABCG8 Apolipoprotein \\
\hline & 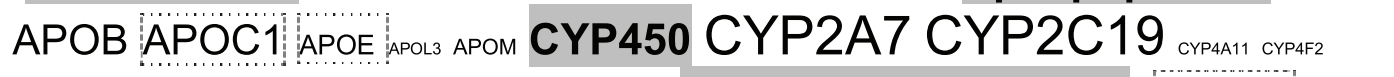 \\
\hline & cYP11B2 CYP24A1 CYP2U1 Lipoprotein receptors LDLR \\
\hline & LDLRAD2 LDLRAD2 PLA2G15 LRP1 LRP2 LRP3 LRP4 LRP6 LRP9 LRP10 LRP11 \\
\hline & LRP12 Cholesterol metabolism/transport CES2 CHST6 DHсR2 DHCR7 \\
\hline & EBP HMGcR Hмcсs2 LSS MSR1 NPC1 NPC2OSBP osBPL2 scP2 SORBS1 \\
\hline & Cholesterol/lipoprotein transcription factor SREBF1SREBF2 \\
\hline & MISCELLANEOUS \\
\hline & ACSM1ACAA2 ACADB: ALOXE3 ALOX5 ALOX12B aLox15B AMOT \\
\hline & ATMIN ATP2B2 ATP2C1 ARHGAP33 BUD13 CAL CD320 сDкN1C \\
\hline & cebpd CELsR2 CFDP1 CFI CHRM1 CHST5 C8B clec3A CRHR1 CUBN \\
\hline & DGAT1 DISC1:DPP7 FXDR GABRA2 GHRH GULP1 IL28A INSR IRS4 KCNV2 KDR \\
\hline & KL KLB KLRAQ1 \\
\hline & 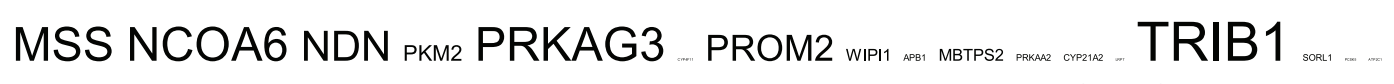 \\
\hline & PRKAG2 PTGIS RAB7L1 _. RAB8A S4 SBF2 SCAND1 SLC6A9 \\
\hline & SLC27A1 ST14 SULT2B1 \\
\hline & TOMM40 \\
\hline
\end{tabular}


TABle 2: Continued.

\begin{tabular}{|c|c|}
\hline BLAST filter & Gene products with homology to HSV-1 proteins \\
\hline \multirow{14}{*}{ HSV-1 No Filter } & KINASES ARAF _. BRAF CAMK1D CAMK1G CAMK2B CAMK2D \\
\hline & CAMK2G CDK1 \\
\hline & CDK16 CDKL1 $1_{\text {сокL2 }}$ сдкц4 $\mathrm{CDKL} 5$ CHEK2 снUк DCLK2 дмPK еІгакз \\
\hline & EIF2AK4 GSK3A GSK3B \\
\hline & MAPK6 MAPK8 MAPK12 MAPK14 MAP2K2 маРзК2 MAP3K3 мАР3К4 \\
\hline & MAP3K12 марзк1з мар4к1 MARK2 MARK3 MARK4 MYLK NEK3 \\
\hline & NEK9 NEK11 NUAK1NUAK2 PAK1 РАКз PAK6 PASK PCNK \\
\hline & 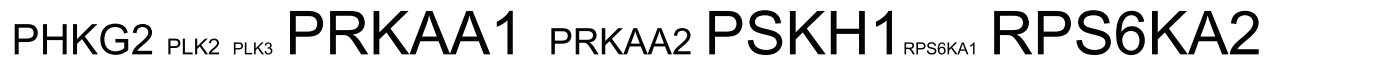 \\
\hline & RPS6KA3 RPS6KA6 SBK2 SGK1 sGk494 sıK1 sLK SNRK STK10 \\
\hline & $\begin{array}{l}\text { STK24 sтK25 sткз5 sткз9 TAOK1 TAOK2 } \\
\text { тssк2 } \\
\text { MISCELLANEOUS }\end{array}$ \\
\hline & ADAMTS17 APOA1BP APBB1 CEP250 c4A col25Al DNM3 ElF3F \\
\hline & EIF3FP3 FADD LAMA3 LATS1 LOR MASTL MST4 NIM1 NTN1 \\
\hline & OXSR1 $1_{\text {PICAL POLA1 }}$ POLD1 _ _. RAGE REV3L RRM2B STARD9 \\
\hline & 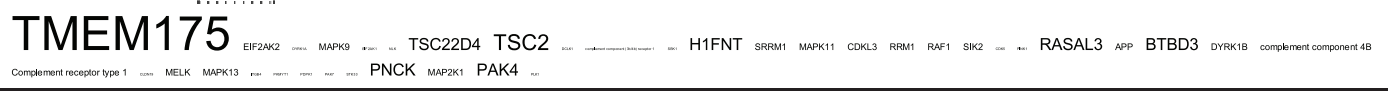 \\
\hline
\end{tabular}

[21], Human herpesvirus 6, and Human herpesvirus 5 (Cytomegalovirus) [22].

Cryptococcus neoformans infection has been shown to be associated with a rare but curable form of dementia in two separate studies, where both patients had been consigned to healthcare for 3 years, with a diagnosis of Alzheimer's disease. Both recovered normal function following antifungal treatment $[23,24]$. Heliocobacter pylori eradication has also been reported to improve cognitive function in Alzheimer's disease [25].

The protein sequences highlighted in grey in Table 3 contain strings of herpes simplex proteins that have been shown to bind to several interactome partners of tau [11] (see http://www.polygenicpathways.co.uk/herpeshost.htm) and are those most likely to form epitopes that cross-react with their human counterparts (Table 1). These include APOE4, complement receptor 1, clusterin, insulin degrading enzyme, the APP homologue, APLP2, the APP binding protein APBBI1P, the collagen amyloid plaque component CLAC, synuclein, and the foetal Alzheimer antigen, ALZ50. Tau appears to be highly antigenic (Table 2).

This antigenicity was further studied for the two key proteins in Alzheimer's disease, beta-amyloid and tau, and the predicted immune epitopes compared with the HSV-1 viral proteins aligning within these various regions (Figures 2 and 3 ).

\section{Vatches within Beta-Amyloid and the Microtubule Protein tau}

Vatches (= viralmatches) are short contiguous amino acid stretches that are identical in viral and human proteins $[26,27]$. There are several million within the human proteome, derived from evolutionary descent and from the insertion of multiple viruses into the human genome over millions of years. This type of insertion is not restricted to retroviruses, as herpes viruses, hepatitis viruses, influenza and the common cold virus, the coronavirus, and the papillomavirus, among others, have all been inserted into different genomic regions or are homologous to the encoded protein products. This has occurred on several occasions during evolutionary time, and these reinsertions appear to be responsible for the creation of gene families (see http://www.polygenicpathways.co.uk/blasts.htm), where over 2 million such alignments are available for multiple viral species. In effect, the entire human genome appears to be composed of viral DNA. For example, the coverage of human chromosome 10 is complete, with 119,867 human/viral DNA matches.

A single HSV-1 vatch, translated back to DNA, is identical to DNA in 103 different genomic regions covering several human chromosomes. This phenomenon is likely responsible for the creation of gene families, and the HSV-1 
TABLE 3: Major susceptibility gene products and members of other key signalling networks in Alzheimer's disease (Sbjct) aligning with the translated HSV-1 genome (Query). The 6 amino acids with the highest B cell antigenicity index are highlighted in grey (see Table 1). Spaces denote a nonidentical amino acid; dashes represent gaps and $+=$ conserved amino acid (similar physicochemical properties).

\begin{tabular}{|c|c|c|c|}
\hline \multirow{4}{*}{$\begin{array}{l}\text { Human protein } \\
\\
\text { APOE4 } \\
\text { 1B68A GI:15826311 }\end{array}$} & \multicolumn{3}{|c|}{ Alignment with the HSV-1 translated genome } \\
\hline & Query 139585 & VRG RLV & 139568 \\
\hline & & VRG RLV & \\
\hline & Sbjct 111 & VRG RLV & 116 \\
\hline \multirow{3}{*}{$\begin{array}{l}\text { PICALM NP_009097.2 } \\
\text { phosphatidylinositol binding clathrin } \\
\text { assembly protein }\end{array}$} & Query 35856 & P ATTP T & 35873 \\
\hline & & P ATTP T & \\
\hline & Sbjct 601 & P ATTP T & 606 \\
\hline \multirow{3}{*}{$\begin{array}{l}\text { Complement receptor } 1 \text { complement } \\
\text { receptor type } 1 \text { isoform S precursor } \\
\text { NP_000642.3 }\end{array}$} & Query 39696 & SSPPPR & 39679 \\
\hline & & SSPPPR & \\
\hline & Sbjct 2029 & SSPPPR & 2034 \\
\hline \multirow{3}{*}{ Clusterin isoform 1 NP_001822 } & Query 48155 & SPGGAR & 48138 \\
\hline & & SPGGAR & \\
\hline & Sbjct 30 & SPGGAR & 35 \\
\hline \multicolumn{4}{|l|}{ APP processing and related } \\
\hline \multirow{3}{*}{$\begin{array}{l}\text { 3DXCA chain A, crystal structure of the } \\
\text { intracellular domain of human APP in } \\
\text { complex with Fe65 }\end{array}$} & Query 78347 & TE AVLG & 78364 \\
\hline & & TE AVLG & \\
\hline & Sbjct 64 & TE AVLG & 69 \\
\hline \multirow{3}{*}{$\begin{array}{l}\text { EAX09965.1 amyloid beta (A4) } \\
\text { precursor protein (peptidase nexin-II, } \\
\text { Alzheimer) }\end{array}$} & Query 102020 & RD P S E LRNTAAS G PD & 102064 \\
\hline & & RDP L TAAS PD & \\
\hline & Sbjct 359 & RDP VKLP TTAAS TP D & 373 \\
\hline \multirow{3}{*}{$\begin{array}{l}\text { NP_958816.1 amyloid beta A4 protein } \\
\text { isoform b precursor }\end{array}$} & Query 75494 & AEEIAD QV-E ILVD QTE & 75447 \\
\hline & & AEEI D+ VE L QE & \\
\hline & Sbjct 536 & AEEIQD E VD E LL--QKE & 550 \\
\hline \multirow{3}{*}{$\begin{array}{l}\text { NP_620428.1 beta-secretase } 1 \text { isoform B } \\
\text { preproprotein }\end{array}$} & Query 96347 & WS LLWLG AG V & 96376 \\
\hline & & W LLW+GAGV & \\
\hline & Sbjct 7 & WLLLWMG AG V & 16 \\
\hline \multirow{3}{*}{$\begin{array}{l}\text { NP_620477.1 beta-secretase } 2 \text { isoform B } \\
\text { preproprotein BACE2 }\end{array}$} & Query 148387 & ARATL-P VMKE LLLRAAP E & 148334 \\
\hline & & ARA L P LLRAAPE & \\
\hline & Sbjct 5 & ARALLLP LLAQWLLRAAP E & 23 \\
\hline \multirow{6}{*}{$\begin{array}{l}\text { AAM92013.1beta-site APP-cleaving } \\
\text { enzyme BACE1 }\end{array}$} & Query 59005 & IFD RTRKFVLACP RAG F & 58955 \\
\hline & & + FDR RK $\quad$ R GF & \\
\hline & Sbjct 59 & VFD RARK- - - - - - RIG F & 69 \\
\hline & Query 115596 & AVS ACQV & 115576 \\
\hline & & $\mathrm{AVSAC}+\mathrm{V}$ & \\
\hline & Sbjct 70 & AVS ACHV & 76 \\
\hline \multirow{3}{*}{$\begin{array}{l}\text { EAW81096.1 presenilin } 1 \text { (Alzheimer } \\
\text { disease 3), isoform CRA_f }\end{array}$} & Query 134424 & FLP E WTVAW & 134398 \\
\hline & & + LPE WT AW & \\
\hline & Sbjct 240 & YLP E WT- AW & 247 \\
\hline \multirow{3}{*}{$\begin{array}{l}\text { EAW69799.1 presenilin } 2 \text { (Alzheimer } \\
\text { disease 4), isoform CRA_d }\end{array}$} & Query 40896 & ALP P LP IS & 40873 \\
\hline & & ALP LPIS & \\
\hline & Sbjct 152 & ALP ALPIS & 159 \\
\hline
\end{tabular}


TABle 3: Continued.

\begin{tabular}{|c|c|c|c|}
\hline Human protein & & Alignment with the HSV-1 translated genome & \\
\hline \multirow{7}{*}{$\begin{array}{l}\text { NP_758844.1 gamma-secretase subunit } \\
\text { PEN-2 }\end{array}$} & Query 151699 & G YVWRS & 151716 \\
\hline & & G YVWRS & \\
\hline & Sbjct 55 & G YVWRS & 60 \\
\hline & Ouprv 142209 & S AVG G LFW & 142186 \\
\hline & 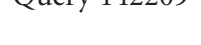 & S AVG LFW & 172100 \\
\hline & & S AVG FLFW & \\
\hline & Sbjct 60 & & 67 \\
\hline \multirow{3}{*}{$\begin{array}{l}\text { NP_004960.2 insulin-degrading enzyme } \\
\text { isoform } 1 \text { precursor }\end{array}$} & Query 25849 & P E D RRE YP G & 25875 \\
\hline & & PED REY G & \\
\hline & Sbjct 58 & P ED KREYRG & 66 \\
\hline \multirow{3}{*}{$\begin{array}{l}\text { NP_061916.3 amyloid beta A4 precursor } \\
\text { protein-binding family B member } \\
\text { interacting protein APBB1IP }\end{array}$} & Query 26756 & D NHLP S P AP P TP -D D IS CG P E LP FAR PP & 26673 \\
\hline & & D+ LP P PP P DD $\quad$ PELP PP & \\
\hline & Sbjct 551 & D D FLPPP P P P P P LD D ---- $\quad$ P E LP ---- PP & 571 \\
\hline \multirow{3}{*}{$\begin{array}{l}\text { NP_004877.1 amyloid beta A4 precursor } \\
\text { protein-binding family A member } 3 \\
\text { [Homo] }\end{array}$} & Query 148163 & LE P AS RLLRLG RP P E & 148119 \\
\hline & & LEP A RLL PPE & \\
\hline & Sbjct 132 & LE P AP RLL - - - QP P E & 143 \\
\hline \multirow{7}{*}{$\begin{array}{l}\text { NP_001633.1 amyloid-like protein } 2 \\
\text { isoform } 1 \text { APLP2 }\end{array}$} & Query 73214 & IS MTP VAVLWE NP D P P G P P D VRFVG SE ATE E LP & 73116 \\
\hline & & $\begin{array}{llllll}\text { IS TPV } & \text { DVR } & V & \text { SE } & \text { EE } & P\end{array}$ & \\
\hline & Sbjct 579 & IS E TP V - - - - - - - D DR-VS S E E S E E IP & 597 \\
\hline & Ouery 63557 & E VVE -RTD VYYYE T & 63595 \\
\hline & 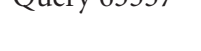 & EVVE R-D YYY+T & הכנסת \\
\hline & & E VVE D R-D -YYYD T & \\
\hline & Sbjct 266 & & 277 \\
\hline \multirow{3}{*}{$\begin{array}{l}\text { NP_001123886.1 amyloid beta A4 } \\
\text { precursor protein-binding family A } \\
\text { member } 2 \text { isoform }\end{array}$} & Query 20300 & LRRG D G D L & 20323 \\
\hline & & LRRGDGDL & \\
\hline & Sbjct 212 & LRRG D G D L & 219 \\
\hline \multirow{3}{*}{$\begin{array}{l}\text { AAL79526.1AF394214_1 adaptor } \\
\text { protein FE65a2 }\end{array}$} & Query 63303 & S S TRG LWTP SH & 63335 \\
\hline & & S S R WTP SH & \\
\hline & Sbjct 572 & SSS REQWTP S H & 582 \\
\hline \multirow{3}{*}{$\begin{array}{l}\text { NP_663722.1 amyloid beta A4 precursor } \\
\text { protein-binding family B member } 1 \\
\text { isoform }\end{array}$} & Query 51630 & RG LRG P VLI & 51604 \\
\hline & & RGLRGP LI & \\
\hline & Sbjct 130 & RG LRG P G LI & 138 \\
\hline \multirow{3}{*}{$\begin{array}{l}\text { Query Q12830.3BPTF_Fetal Alzheimer } \\
\text { antigen } \\
\text { Alz-50 clon }\end{array}$} & Query 41203 & P AP P P FRS ARNTCP LP P S P TAS G P & \\
\hline & & $\begin{array}{llll}\text { PAPPP } & \text { PP } & \text { P } & \text { S GP }\end{array}$ & \\
\hline & Sbjct 22 & P AP P P - . - . - - P P P P P TS G P & \\
\hline \multirow{3}{*}{$\begin{array}{l}\text { Query O94985.1 CSTN1 } \\
\text { Calsyntenin-1 = Alcadein }\end{array}$} & Query 43114 & AS RLLL & 43131 \\
\hline & & A RLLL & \\
\hline & Sbjct 12 & AARLLL & 17 \\
\hline \multirow{3}{*}{$\begin{array}{l}\text { NP_009292.1 alpha-synuclein isoform } \\
\text { NACP112 }\end{array}$} & Query 54520 & E D AVHG VAG V & 54549 \\
\hline & & E VHGVA V & \\
\hline & Sbjct 46 & E G VVHG VATV & 55 \\
\hline \multicolumn{4}{|l|}{ Others } \\
\hline \multirow{3}{*}{$\begin{array}{l}\text { Query } \\
\text { Q07954.1LRP1_HUMAN RecName: } \\
\text { Full=Prolow-density lipoprotein } \\
\text { receptor-related protein }\end{array}$} & Query 92727 & TIHRE TGSG & 92701 \\
\hline & & T+HRETGSG & \\
\hline & Sbjct 1425 & TVHRE TGSG & 1433 \\
\hline
\end{tabular}


Table 3: Continued.

\begin{tabular}{|c|c|c|c|}
\hline Human protein & \multicolumn{3}{|c|}{ Alignment with the HSV-1 translated genome } \\
\hline \multirow{3}{*}{ NP_000577.2 interleukin-2 precursor } & Query 27667 & S AP TS S S & 27647 \\
\hline & & SAPTSSS & \\
\hline & Sbjct 20 & S AP TS S S & 26 \\
\hline \multirow{3}{*}{$\begin{array}{l}\text { NP_002084.2 glycogen synthase } \\
\text { kinase- } 3 \text { beta isoform } 1\end{array}$} & Query 86718 & G RP RTTS & 86698 \\
\hline & & GRPRTTS & \\
\hline & Sbjct 3 & G RPRTTS & 9 \\
\hline \multirow{3}{*}{$\begin{array}{l}\text { NP_065574.3 choline } \\
\text { O-acetyltransferase isoform } 2 \text { [Homo } \\
\text { sap] }\end{array}$} & Query 67995 & AQS AE PRRA----CVP & 68030 \\
\hline & & $\mathrm{A}+$ AEPRRA $\mathrm{C}+\mathrm{P}$ & \\
\hline & Sbjct 87 & AE AAE PRRAG P HLCIP & 102 \\
\hline \multirow{3}{*}{ NP_003947.1 cholesterol 25-hydroxylase } & Query 66447 & WVPALRR & 66467 \\
\hline & & WVPALRR & \\
\hline & Sbjct 64 & WVPALRR & 70 \\
\hline
\end{tabular}

TABLE 4: Alignment of the HSV-1 translated genome (Query) with 3 protein kinases known to phosphorylate tau (Sbjct). Glycogen synthase kinase GSK3A aligns with the same amino acids as GSK3B. CAMK2B: calcium/calmodulin-dependent protein kinase II beta. MAPK1: mitogen-activated protein kinase 1 (erk2).

\begin{tabular}{|c|c|c|c|}
\hline Kinase & & Alignment with HSV-1 proteins & \\
\hline \multirow{9}{*}{ GSK3B and GSK3A } & Query 136083 & QLLSAVDYIHRQGIIHRDIKTENIFINTPE----DICLGDFGAA------------CFV & \\
\hline & & QL $\quad$ YIH $\quad$ GIHRDIK $+\mathrm{N} \quad+\mathrm{P}+\quad$ C $\quad$ DFG A $\quad$ C & \\
\hline & Sbjct 143 & QLFRSLAYIHSFGICHRDIKPQNLLLD-PDTAVLKLC—DFGSAKQ LVRG EPNVSYIC-- & \\
\hline & Query 136212 & QGSRSSPFPYGIAGTIDTNAPEVL--AGDPYTTTVDIWSAG & 136328 \\
\hline & & SR $\quad \mathrm{Y} \quad$ APE $\quad$ A D YT + D+WSAG & \\
\hline & Sbjct 198 & --SR-----Y-------YRAPELIFGATD-YTSSIDVWSAG & 223 \\
\hline & Query 81948 & HPW----RSRTAPGAAALC & 81992 \\
\hline & & HPW R RT P A ALC & \\
\hline & Sbjct 278 & HPWTKVFRPRTPPEAIALC & 296 \\
\hline \multirow{6}{*}{ САМК2B } & Query 136083 & QLLSAVDYIH-RQ-GIIHRDIKTENIFINTPEDI-----C------LGDFGAACFVQG VQG -- & 136217 \\
\hline & & $\begin{array}{llllllll}\text { Q L } & \text { AV } & \text { H } & \text { Q G++HRDK } & \text { PE }+ & \text { C } & \text { L DFG A } & \text { VQG }\end{array}$ & \\
\hline & Sbjct 119 & QILXAV--LHCHQMGVVHRDLK-------- & \\
\hline & Query 136218 & -SRSSPFPYGIAGTIDTNAPEVLAGDPYTTTVDIWSAGLVI & 136337 \\
\hline & & $\begin{array}{lllll}+ \text { G AGT } & \text { PEVL } & +\mathrm{Y} & \text { VDIW } & \text { G VI }\end{array}$ & \\
\hline & Sbjct 169 & QAW-----FGFAGTPGYLSPEVLRKEAYGKPVDIWACG-VI & 203 \\
\hline \multirow{6}{*}{ MAPK1 } & Query 136083 & QLLSAVDYIHRQGIIHRDIKTENIFINTPEDIC----LGDFGAACFVQGSRSSPFPYGI & \\
\hline & & $\begin{array}{lllllllll}\text { QLL } & \text { YIH } & \text { GIIHRD K } & \text { N }++N & \text { ED C } & \text { L } & \text { DFG A } & \text { R }\end{array}$ & \\
\hline & Sbjct 133 & QLLRGLKYIHSAGIIHRDLKPSNVAVN--ED-CELRIL-DFGLA------RQ-------A & 175 \\
\hline & Query 136251 & -----GTIDT---NAPEVL-----AGDPYTTTVDIWSAG & 136328 \\
\hline & & $\begin{array}{llll}\mathbf{G}+\mathrm{T} & \mathrm{APE}++ & \mathrm{Y} & \text { TVDIWS G }\end{array}$ & \\
\hline & Sbjct 176 & DEEMTGYVATRWYRAPEIMLNWMH----YNQTVDIWSVG & 210 \\
\hline
\end{tabular}

virus appears to have been partly responsible for the creation of lipoprotein receptor families (Figure 1), and of numerous kinases within a number of different families (see above and Table 2). Over millions of years, these DNA inserts have been extensively shuffled by recombination, but millions of consecutive sequences are retained that encode for the viral matching protein components.

Some of the vatches within beta-amyloid and tau are illustrated in Figures 2 and 3 which also demonstrates the
$\mathrm{B}$ cell and $\mathrm{T}$ cell antigenicity of these proteins. As can be seen, there are numerous HSV-1 vatches within both proteins, many of which correspond to highly antigenic regions of APP or tau, and therefore also of the HSV-1 proteins.

In addition to the herpes simplex virus, a large number of other viruses express proteins containing a VGGVV sequence that is identical to that of a C-terminus peptide within beta-amyloid. Although not the most immunogenic 
TABLE 5: Other viruses expressing homologous proteins for the four major Alzheimer's disease susceptibility gene products.

\begin{tabular}{|c|c|c|}
\hline Alzheimer's gene & Viral protein & Identical amino acid sequences (vatches) \\
\hline \multirow{9}{*}{$\begin{array}{l}\text { APOE4 } \\
\text { Chain A, } \\
\text { Apolipoprotein E4 } \\
\text { (Apoe4), 22k } \\
\text { Fragment. } \\
\text { ACCESSION } \\
\text { 1B68_A }\end{array}$} & ACE82482 polyprotein Hepatitis C virus subtype 1a & GADMEDV \\
\hline & YP_002455799 tape measure protein Lactobacillus phage Lv-1 & MKELKA \\
\hline & $\begin{array}{l}\text { ADD95207 hypothetical protein uncultured phage } \\
\text { MedDCM-OCT-S04-C650 }\end{array}$ & RKRLLR+ ++L K L \\
\hline & YP_002242088 gp31 Mycobacterium phage Konstantine & RKR-----D+LQ-RL----A-G-REGAE-GLS \\
\hline & YP_002922735 gp63 Burkholderia phage BcepIL02 & E EP P Q WQSGQ \\
\hline & NP_612835 major capsid protein Clostridium phage phi3626 & E EP-P----Q--WQSGQ \\
\hline & AAT07716 virion protein human herpesvirus 3 & LEEQLT--A \\
\hline & DAA06495 envelope glycoprotein 24 human herpesvirus 5 & DDL--R-LAVYQA \\
\hline & $\begin{array}{l}\text { YP_001293401 hypothetical protein PPF10_gp057 Pseudomonas phage } \\
\text { F10 }\end{array}$ & MTR---EFLKVA-Q \\
\hline \multirow{9}{*}{$\begin{array}{l}\text { Clusterin isoform } 1 \\
\text { NP_001822.2 }\end{array}$} & ACS93434 capsid portal protein human herpesvirus 5 & QVAERL \\
\hline & CAA35329 HCMVUL127 human herpesvirus 5 & SAINT \\
\hline & $\begin{array}{l}\text { T44166 hypothetical protein U20 imported-human herpesvirus } 6 \\
\text { (strain Z29) }\end{array}$ & $\begin{array}{l}\text { L }+ \text { QTVSD+ } \\
\text { and }\end{array}$ \\
\hline & AF157706_21 U20 human herpesvirus 6B & L LEE K D \\
\hline & P60504ICP47_HSV2S ICP47 protein; & A LRRELD \\
\hline & NP_044506 large tegument protein human herpesvirus 2 & ESGQ LG \\
\hline & AAR12147 US34 human herpesvirus 5 & GSGLV R+L +F \\
\hline & AAA66443 unknown protein human herpesvirus 2 & +SGQVLG--T \\
\hline & D1LR45_9INFA D1LR45 Hemagglutinin Influenza A virus & LIEKTN ++ \\
\hline \multirow{9}{*}{$\begin{array}{l}\text { Clusterin isoform } 2 \\
\text { NP_976084.1 }\end{array}$} & ACS93434 capsid portal protein human herpesvirus 5 & QVAERL \\
\hline & C3U7E2Influenza A virus & KYVNKE and LIEKTN E \\
\hline & $\begin{array}{l}\text { C3VE93 Envelope glycoprotein (Fragment) human immunodeficiency } \\
\text { virus }\end{array}$ & KKKKEDAL \\
\hline & D2XAW9 Restriction endonuclease Marseillevirus & ЕECKРC K \\
\hline & Q5J5Q8 Gp46 Mycobacterium phage & DDDRTVC \\
\hline & $\begin{array}{l}\text { Q9DVL9_9HIV1 Q9DVL9 Envelope glycoprotein gp160 human } \\
\text { immunodeficiency virus }\end{array}$ & NETRE \\
\hline & ORF10 Vibrio phage & $\begin{array}{l}\text { EKALQEY L } \\
\text { RKY ELLK }\end{array}$ \\
\hline & Q2PZB7 RstR-like protein Vibrio phage CTX & LLEQLNE+ \\
\hline & P36272 Portal protein Enterobacteria phage P21 & TEFIREG \\
\hline \multirow{7}{*}{$\begin{array}{l}\text { Clusterin isoform } 3 \\
\text { NP_001164609.1 }\end{array}$} & ACS93434 capsid portal protein human herpesvirus 5 & $\begin{array}{l}\text { QVAERL and } \\
\text { RV GSGLV R+L +F }\end{array}$ \\
\hline & NP_050200 glycoprotein human herpesvirus 6 & L +QTVSD+ \\
\hline & NP_050228 glycoprotein O human herpesvirus 6 & DESLQ A \\
\hline & YP_001129444 BFLF1 human herpesvirus 4 type 2 & SGVTEV \\
\hline & NP_044506 large tegument protein human herpesvirus 2 & ESGQ LG \\
\hline & AAA66443 unknown protein human herpesvirus 2 & + SGQVLG T \\
\hline & D1LR45 Hemagglutinin Influenza A virus & LIEKTN++ \\
\hline \multirow{8}{*}{$\begin{array}{l}\text { CR1 isoform } \mathrm{f} \\
\text { NP_000564.2 }\end{array}$} & ACL67924 single-stranded DNA-binding protein human herpesvirus 3 & F SCEPS D \\
\hline & P88903_HHV8 P88903 ORF 4 human herpesvirus 8 type $\mathrm{M} \mathrm{PE}=4 \mathrm{SV}=1$ & WDPPL KC \\
\hline & AAD49671AF157706_89 U79 human herpesvirus 6B & SVPVCE \\
\hline & $\begin{array}{l}\text { ABI63477 UL15 human herpesvirus } 1 \\
\text { CAB06775 UL15 human herpesvirus } 2\end{array}$ & Y+LRGAA \\
\hline & ACN63150 pUL27 human herpesvirus 5 & $\begin{array}{l}\text { VRAG C TPE } \\
+ \text { RCRRK }\end{array}$ \\
\hline & ACS92020 tegument protein UL14 human herpesvirus 5 & L+GS SATC \\
\hline & $\begin{array}{l}\text { NP_042926 protein UL49 human herpesvirus } 6 \\
\text { BAA78254 capsid protein human herpesvirus } 6 \mathrm{~B}\end{array}$ & HCVL-GMK \\
\hline & $\begin{array}{l}\text { ABI63477 UL15 human herpesvirus } 1 \\
\text { NP_044484 DNA packaging terminase subunit } 1 \text { human herpesvirus } 2\end{array}$ & Y+LRGAA \\
\hline
\end{tabular}


TABle 5: Continued.

\begin{tabular}{|c|c|c|}
\hline Alzheimer's gene & Viral protein & Identical amino acid sequences (vatches) \\
\hline & CAA35376 HCMVUL61 human herpesvirus 5 & GPPAP LP \\
\hline & $\begin{array}{l}\text { :Q01016-2 Q01016 Isoform } 2 \text { of Complement control protein homolog } \\
\text { Saimiriine herpesvirus } 2\end{array}$ & WDPPL-KC \\
\hline & $\begin{array}{l}\text { :Q01016-2 Q01016 Isoform } 2 \text { of Complement control protein homolog } \\
\text { Saimiriine herpesvirus } 2 \text { (strain 11) }\end{array}$ & GSVVTY CN G \\
\hline \multirow{8}{*}{$\begin{array}{l}\text { CR1 isoform S } \\
\text { NP_000642.3 }\end{array}$} & Q2HRD4 ORF4 human herpesvirus 8 type P (isolate GK18) & WDPPL KC \\
\hline & $\begin{array}{l}\text { ACL51139 helicase-primase primase subunit human herpesvirus } 5 \\
\text { NP_050259 DNA replication human herpesvirus } 6 \\
\text { AAD49671AF157706_89 U79 human herpesvirus 6B }\end{array}$ & SVPVCE \\
\hline & AAR84398 ORF_03L Herpes simplex virus 1 strain R-15 & SSPPPR \\
\hline & $\begin{array}{l}\text { CAA58413 U33 human herpesvirus } 6 \\
\text { BAA78254 capsid protein human herpesvirus 6B }\end{array}$ & HCVL GMK \\
\hline & CAA35376 HCMVUL61 human herpesvirus 5 & GPPAP LP \\
\hline & NP_044484 DNA packaging terminase subunit 1 human herpesvirus 2 & Y+LRGAA \\
\hline & NP_042966 DNA replication origin-binding helicase human herpesvirus 6 & TINGDF \\
\hline & Q2HRD4 ORF4 human herpesvirus 8 type P (isolate GK18) & WDPPL KC \\
\hline \multirow{19}{*}{$\begin{array}{l}\text { PICALM } \\
\text { NP_001008660.1 }\end{array}$} & AAR84403 ORF_08L Herpes simplex virus 1 strain R-15 & TGSAVS \\
\hline & $\begin{array}{l}\text { ABX74960 dihydrofolate reductase-like protein Retroperitoneal } \\
\text { fibromatosis-associated herpesvirus }\end{array}$ & SLTTAA-P \\
\hline & CAA32311 very large tegument protein human herpesvirus 1 & FD-LGGLL \\
\hline & AAP88252 UL74 protein human herpesvirus 5 & LKEQ-LK \\
\hline & ABF22039 DNA polymerase catalytic subunit human herpesvirus 3 & NPFLT--SG \\
\hline & BAA86355 polyprotein Hepatitis C virus & FTPSPV \\
\hline & NP_899479 hypothetical protein KVP40.0233 Vibrio phage KVP40 & IRLFAA-YN+ \\
\hline & ADD94131 hypothetical protein uncultured phage & LKALKEQ-L \\
\hline & MedDCM-OCT-S04-C1161 & \multirow{2}{*}{ SKTVCK T } \\
\hline & NP_671655 EVM136 Ectromelia virus & \\
\hline & $\begin{array}{l}\text { AAM92151AF436128_1 putative transforming protein E6 human } \\
\text { papillomavirus_-cand } 89\end{array}$ & MVY-NERF \\
\hline & YP_002727871 putative structural protein Pseudomonas phage phikF77 & QYLA-RNT \\
\hline & AAT73600 minor tail protein Lactococcus phage 943 & SIVUDFS \\
\hline & BAE44071 polyprotein human coxsackievirus A24 & 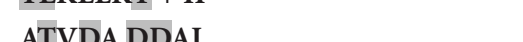 \\
\hline & ADD25709 putative phage structural protein Lactococcus phage 1358 & IRLFAA YN+ \\
\hline & NP_899479 hypothetical protein KVP40.0233 Vibrio phage KVP40 & ITTHHL--MV \\
\hline & YP_238567 ORF319 Staphylococcus phage Twort & TEKLLKT-+--II \\
\hline & BAE44071 polyprotein human coxsackievirus A24 & \multirow{2}{*}{ AL E Q LKALKE+ } \\
\hline & $\begin{array}{l}\text { YP_002332459 hypothetical protein PPMP29_gp34 Pseudomonas phage } \\
\text { MP29 }\end{array}$ & \\
\hline
\end{tabular}

of sequences, this epitope has been used to label beta-amyloid in Alzheimer's disease brain [28] (Figure 2).

\section{HSV-1 Proteins Bind to the Interaction Partners of tau}

Because HSV-1 proteins are homologous to portions of the tau protein, one might expect the viral proteins to interfere with tau binding partners. This is indeed the case, as diverse herpes simplex viral proteins have been shown to bind to several of the interactome partners of tau (Table 6).

\section{Discussion}

Almost without exception, the genes encoding the proteins that match HSV-1 sequences (using the filter "Alzheimer") have been reported as genetic risk fac-tors in Alzheimer's disease (see http://www.polygenicpathways. co.uk/alzpolys.html) suggesting that such studies have been tracking HSV-1 (and other) infections over the years and inadvertently demonstrating that HSV-1 causes Alz-heimer's disease. This in no way detracts from the importance of these studies, but reflects a phenomenon that is probably common to most diseases. Because of our likely evolutionary 
TABLE 6: The binding partners of tau (from the interaction section of NCBI gene) and their interaction with herpes simplex proteins (from the Wikigenes database) [11]; https://www.wikigenes.org/e/art/e/61.html.

\begin{tabular}{|c|c|c|}
\hline Gene symbol & Name & Interaction with $\mathrm{HSV}-1$ proteins \\
\hline AATF & Apoptosis antagonizing transcription factor & - \\
\hline ABL1 & V-abl Abelson murine leukemia viral oncogene homolog 1 & - \\
\hline АСТВ & Actin, beta & Virion component \\
\hline APOE & Apolipoprotein E & Binds to glycoprotein B \\
\hline BAG1 & BCL2-associated athanogene & - \\
\hline CALM1 & Calmodulin 1 (phosphorylase kinase, delta) & Phosphorylated by ICP10 \\
\hline CAMK2A & $\begin{array}{l}\text { Calcium/calmodulin-dependent protein kinase (CaM kinase) } \\
\text { II alpha }\end{array}$ & - \\
\hline CASP1 & $\begin{array}{l}\text { Caspase } 1 \text {, apoptosis-related cysteine peptidase (interleukin } \\
1 \text {, beta, convertase) }\end{array}$ & - \\
\hline CASP3 & Caspase 3, apoptosis-related cysteine peptidase & US3 phosphorylates procaspase 3 \\
\hline CASP6 & Caspase 6, apoptosis-related cysteine peptidase & - \\
\hline CASP7 & Caspase 7, apoptosis-related cysteine peptidase & Activated during HSV-1 mediated apoptosis \\
\hline CASP8 & Caspase 8 , apoptosis-related cysteine peptidase & Activity inhibited by LAT latency transcript \\
\hline CDK1 & Cyclin-dependent kinase 1 & - \\
\hline CDK5 & Cyclin-dependent kinase 5 & - \\
\hline FLJ10357 & Hypothetical protein FLJ10357 & - \\
\hline FYN & FYN oncogene related to SRC, FGR, YES & - \\
\hline GSK3A & Glycogen synthase kinase 3 alpha & - \\
\hline GSK3B & Glycogen synthase kinase 3 beta & Activated by HSV-1 infection \\
\hline HSPA8 & Heat shock $70 \mathrm{kDa}$ protein 8 & $\begin{array}{l}\text { Recruited to nuclear domains following infection: } \\
\text { ICP0 dependent }\end{array}$ \\
\hline MAPK12 & Mitogen-activated protein kinase 12 & - \\
\hline MAPT & Microtubule-associated protein tau & $\begin{array}{l}\text { Phosphorylated by viral infection via GSK3B and } \\
\text { PRKACA }\end{array}$ \\
\hline MARK1 & MAP/microtubule affinity-regulating kinase 1 & - \\
\hline MARK4 & MAP/microtubule affinity-regulating kinase 4 & - \\
\hline OGT & $\begin{array}{l}\text { O-linked N-acetylglucosamine (GlcNAc) transferase (UDP- } \\
\mathrm{N} \text {-acetylglucosamine:polypeptide-N-acetylglucosaminyl } \\
\text { transferase) }\end{array}$ & - \\
\hline PARK2 & Parkinson disease (autosomal recessive, juvenile) 2, parkin & - \\
\hline PHKG1 & Phosphorylase kinase, gamma 1 (muscle) & - \\
\hline PIN1 & $\begin{array}{l}\text { Protein (peptidylprolyl cis/trans isomerase) } \\
\text { NIMA-interacting } 1\end{array}$ & - \\
\hline PKN1 & Protein kinase N1 & - \\
\hline PPP2CA & $\begin{array}{l}\text { Protein phosphatase } 2 \text { (formerly } 2 \mathrm{~A} \text { ), catalytic subunit, alpha } \\
\text { isoform }\end{array}$ & - \\
\hline PPP2CB & $\begin{array}{l}\text { Protein phosphatase } 2 \text { (formerly } 2 \mathrm{~A} \text { ), catalytic subunit, beta } \\
\text { isoform }\end{array}$ & - \\
\hline PPP2R5A & Protein phosphatase 2 , regulatory subunit $\mathrm{B}^{\prime}$, alpha isoform & - \\
\hline PPP5C & Protein phosphatase 5, catalytic subunit & - \\
\hline PRKCD & Protein kinase $\mathrm{C}$, delta & - \\
\hline PSEN1 & Presenilin 1 (Alzheimer disease 3) & - \\
\hline RPS6KA3 & Ribosomal protein S6 kinase, $90 \mathrm{kDa}$, polypeptide 3 & - \\
\hline RPS6KB1 & Ribosomal protein S6 kinase, $70 \mathrm{kDa}$, polypeptide 1 & - \\
\hline S100B & S100 calcium binding protein $\mathrm{B}$ & - \\
\hline
\end{tabular}


TABle 6: Continued.

\begin{tabular}{|c|c|c|}
\hline Gene symbol & Name & Interaction with HSV-1 proteins \\
\hline SNCA & Synuclein, alpha (non-A4 component of amyloid precursor) & - \\
\hline SPTB & $\begin{array}{l}\text { Spectrin, beta, erythrocytic (includes spherocytosis, clinical } \\
\text { type I) }\end{array}$ & - \\
\hline STAU1 & Staufen, RNA binding protein, homolog 1 (Drosophila) & - \\
\hline STUB1 & STIP1 homology and U-box containing protein 1 & - \\
\hline STXBP1 & Syntaxin binding protein 1 & - \\
\hline TUBA4A & Tubulin, alpha $4 \mathrm{a}$ & - \\
\hline TUBB & Tubulin, beta & - \\
\hline UBC & Ubiquitin C & Virion component \\
\hline YWHAB & $\begin{array}{l}\text { Tyrosine } 3 \text {-monooxygenase/tryptophan } 5 \text {-monooxygenase } \\
\text { activation protein, beta polypeptide }\end{array}$ & - \\
\hline YWHAZ & $\begin{array}{l}\text { Tyrosine } 3 \text {-monooxygenase/tryptophan } 5 \text {-monooxygenase } \\
\text { activation protein, zeta polypeptide }\end{array}$ & Virion component \\
\hline
\end{tabular}

HSV-1 protein BLAST versus human proteins: filter $=$ lipoprotein

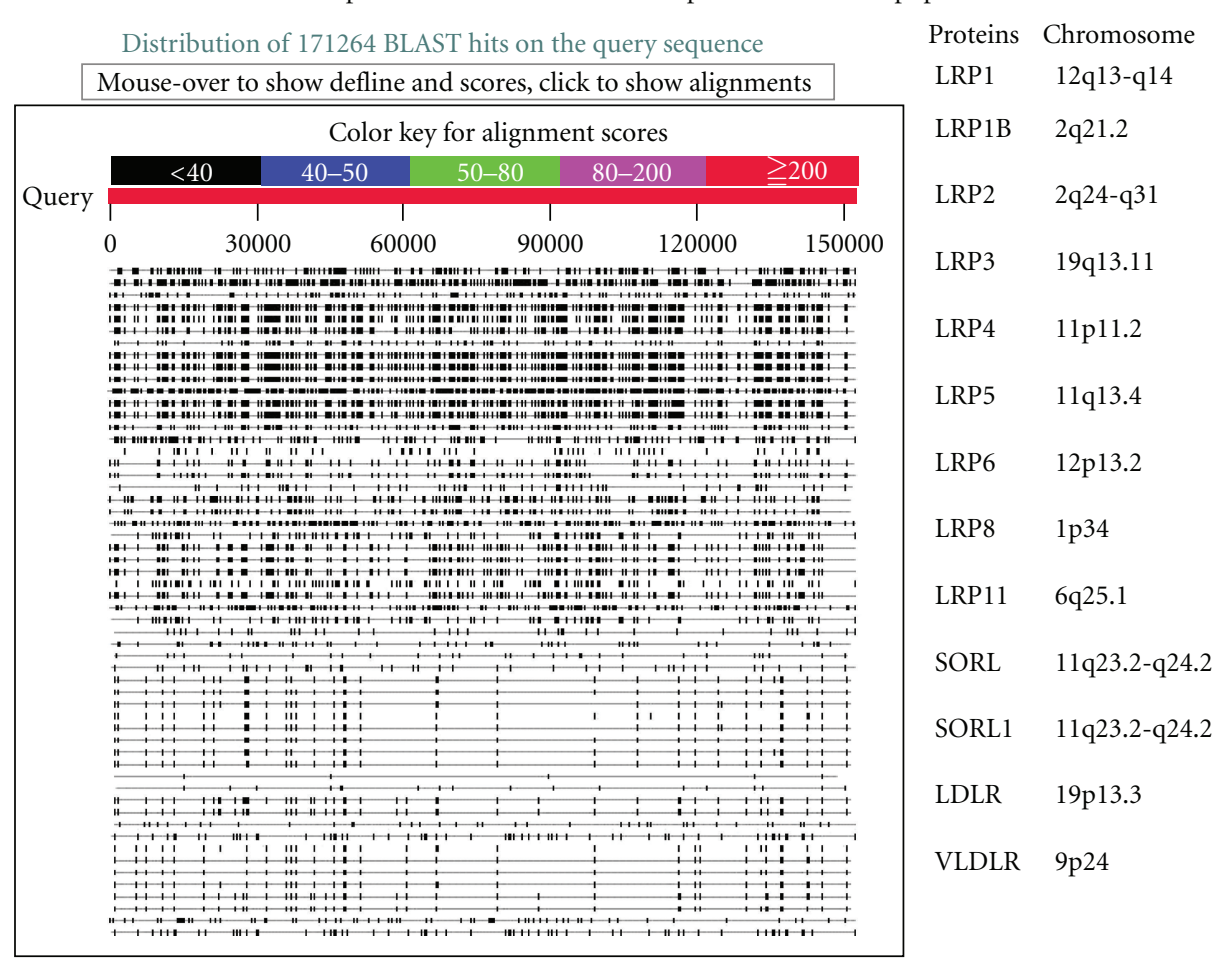

FIGURE 1: The BLAST result for HSV-1 proteins (translated viral genome versus human proteins) using the filter "lipoprotein." The repetitive patterns in the pictogram reflect homology with a number of different lipoprotein receptors located on different chromosomes, as shown in the table.

descent from viruses, first opined by J.B.S. Haldane and Francois D'Herelle almost a century ago [29, 30], our genomes contain traces of this descent which are transcribed into these short contiguous amino acid stretches (vatches) that exactly match many of the proteins in the current virome. Repeated viral insertions also add several genes to the human genome at once, a phenomenon that is likely responsible for evolutionary jumps, as suggested by others [31]. The idea that higher forms of life originated from viruses, although contentious, is supported by the fact that the entire human genome appears to be comprised of viral DNA. For example a BLAST of human chromosome 10 against all viral genomes (DNA versus DNA) returned 119,867 hits, covering the entire chromosome, with no gaps, in both inter- and intragenic regions (see http:// www.polygenicpathways.co.uk/viralimages.htm). Similar results were obtained for other chromosomes. Our genomes and polymorphisms thus determine which vatches we possess, which viruses pose the threat, and which viralrelated disease we are likely to develop. Whether we develop 
the disease in question will depend on our encounters with the virus, whether we are vaccinated, and no doubt on our HLA-antigens and immune background related to the elimination of self-antibodies soon after birth.

This phenomenon appears to be universal, as vatches have been found in the XMRV virus, relating to human proteins involved in mitochondrial respiration and prostate cancer, in the Epstein-Barr virus, which matches multiple sclerosis autoantigens [27], in the AIDS virus which targets vatches in over 50 components of the human immune network, in the papillomavirus which targets cervical cancer oncogenes, and in the HSV-2 virus which targets schizophrenia susceptibility gene products (see http://www. polygenicpathways.co.uk/BLASTS.htm). It is even relevant to human genetic diseases as the polyglutamine repeats observed in Huntington's disease and spinocerebellar ataxias align with very common viruses (the ubiquitous HHV-6) while the cystic fibrosis mutant aligns with pseudomonas and staphylococcal phages, whose bacterial hosts have been found to shorten the lifespan of these patients. The London mutation in Alzheimer's disease converts the surrounding peptide to a vatch that is homologous to proteins from the rhinoviruses that cause the common cold [26, 27, 32, 33]. Every human protein so far screened by the author, without a single exception, displays this type of homology to particular but specific sets of virus for each protein. Similarly all viruses so far screened $(\sim 30)$ express proteins with homology to a large but specific subset of human proteins.

These viral homologues may interfere with Alzheimer's disease pathological pathways in a number of ways. Firstly, as demonstrated by the complement receptor $1 \mathrm{HSV}-1$ viral mimic, the viral protein can substitute for its human counterpart, presumably diverting its function towards different compartments. Secondly, as they are clearly able to substitute for their human counterparts, they are likely to interfere with their protein/protein networks (interactome). This was clearly demonstrated for tau, where herpes simplex virus proteins do indeed bind to tau binding partners.

As many of these matching sequences are highly immunogenic, antibodies to the virus may also target the human homologue, in effect producing a protein knockdown and reproducing the effects, but on a massive scale, seen in various Alzheimer's disease-related knockout mice [3439]. Such immunogenic viral proteins may also generate antibodies capable of mounting an immune attack against their human counterparts, killing the cells in which they reside by immune and inflammatory mechanisms, and by complement-related lysis (see below).

\section{The Dangers of Autoimmunity}

The immunogenic profile of some of these homologues may also be responsible for the neurodegeneration and pathological features observed in Alzheimer's disease. Antibodies to the human proteins may result in immune, inflammation, and complement pathway activation, killing the cells in which the human homologue resides. There is a great deal of evidence supporting autoimmune attack in the Alzheimer's disease brain.

A number of immune-system-related proteins are found in amyloid plaques or neurofibrillary tangles. Interleukin 1 alpha, interleukin 6, and tumour necrosis factor are all been localised within plaques, and acute phase proteins involved in inflammation, such as amyloid $\mathrm{P}$, alpha- 1 antichymotrypsin, and C-reactive protein are also plaque components while immunoglobulin $\mathrm{G}$ is located in the plaque corona $[14,40-$ 42]. Large increases in IgG levels have been recorded in the brain parenchyma, in apoptotic dying neurones, and in cerebral blood vessels in the Alzheimer's disease brain [43]. Complement component C3 is found in Alzheimer's disease amyloid plaques along with complement C4 [44]. Complement components Clq, C3d, and C4d are present in plaques, dystrophic neuritis, and neurofibrillary tangles [45].

The membrane attack complex (MAC), composed of complement proteins $\mathrm{C} 5$ to $\mathrm{C}$, forms a channel that is inserted into the membranes of pathogens, destroying them by lysis. These components cannot be detected in temporal cortex amyloid plaques in Alzheimer's disease [41, 44, 46]. However the MAC complex is present in dystrophic neurites and neurofibrillary tangles [45], and others have detected this complex in neuritic plaques and tangles, along with deposition of C1q, C3, and clusterin [47]. The membrane attack complex has also been detected in the neuronal cytoplasm in AD brains and associated with neurofibrillary tangles and lysosomes [46]. The presence of the MAC complex in neurones might suggest that neuronal lysis by the MAC complex could contribute to neuronal cell death [45].

The microtubule protein tau was one of the more antigenic proteins revealed in this survey and one with numerous matches to herpes viral proteins that would be equally immunogenic. Immunisation with tau in mice produces tauopathy, neurofibrillary tangles, axonal damage, and gliosis [48] demonstrating the dangers of autoimmunity in a manner directly relevant to Alzheimer's disease.

Beta-amyloid autoantibodies are common in the ageing population and in Alzheimer's disease and may be related to herpes simplex and numerous other viruses or phage proteins that exactly vatch a VGGVV C-terminal sequence in beta-amyloid that is immunogenic. The epitope for this sequence labels beta-amyloid in the Alzheimer's brain [28]. This pentapeptide is, per se, fibrillogenic [49]. This is a characteristic of both beta-amyloid and of HSV-1 glycoprotein B peptide fragments containing this sequence. The viral glycoprotein B fragments form thioflavin T positive fibrils which accelerate beta-amyloid fibril formation and are neurotoxic in cell culture [50]. Other stretches of betaamyloid are homologous to a diverse set of viral, bacterial, fungal, and allergenic proteins, likely providing the source of the autoantibodies in the ageing population [32].

Antibodies to beta-amyloid have been suggested as a therapeutic option in Alzheimer's disease. The potential use of beta-amyloid antibodies is based on their ability to reduce plaque burden and neurite dystrophy in APP transgenic mice [51]. Several studies have demonstrated that beta-amyloid antibodies reduce plaque burden in APP transgenic models and that they can also improve cognitive 


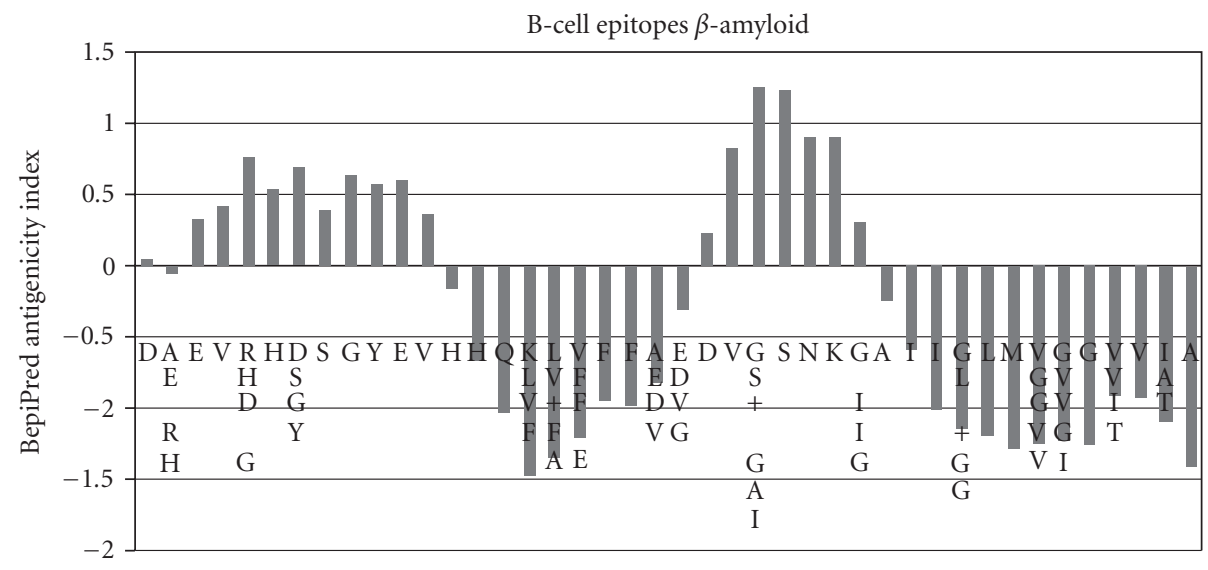

(a)

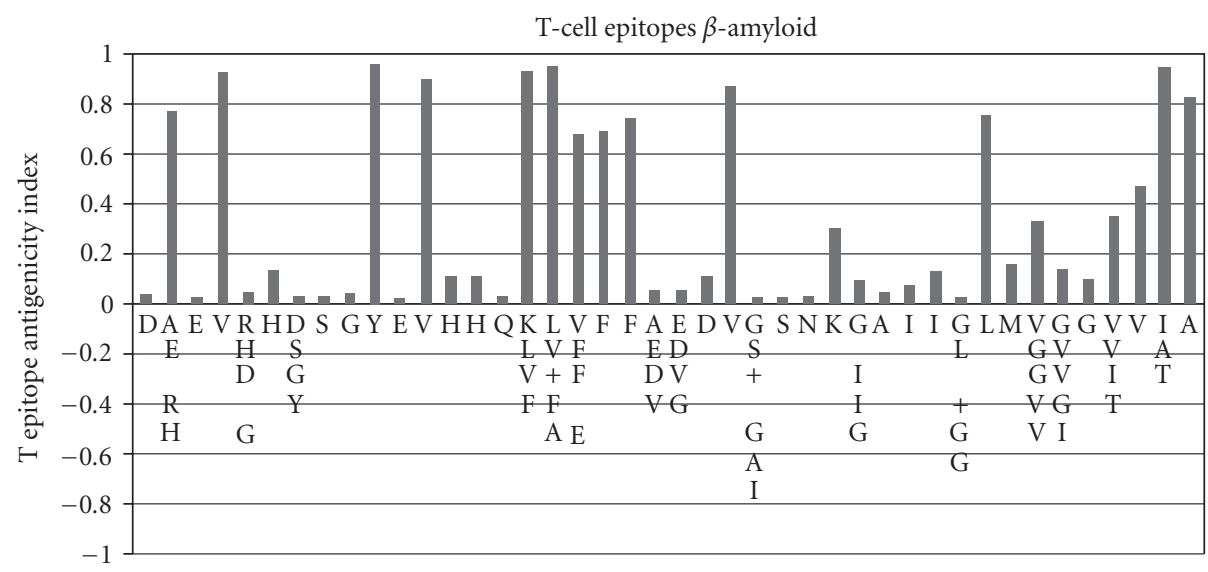

VGGVV: Aeromonas phage, Allpahuayo virus, Clostridium phage, Dengue virus, Ectromelia virus, Enterobacteria phage, Escherichia phage, Feline Calicivirus, Haemophilusphage, Halomonas phage, Hepatitis C, Hepatitis delta, HHV-6, HHV-6B, HSV-1, HSV-2, Human coronavirus, Human enterovirus, Human immunodeficiency virus 1, Human adenovirus 8, Iguape virus, Infectious bronchitis virus, Lactate dehydrogenaseelevatin g virus, Lactococcus phage, Microcystis phage, Mycobacterium phage, Polyomavirus HPyV7, Prochlorococcus phage, Pseudomonas phage, Roseophage, Salmonella phage, Shigella phage, Streptococcus, phage, Synechococcus phage, Variola virus, Vibrio phage, Viral hemorrhagic septicemia virus, Yellow fever

(b)

FIGURE 2: The B cell and T cell immunogenicity profile for the beta-amyloid peptide. According to the servers, antigenicity values of $>0.35$ (B cell) or 0.5 ( $\mathrm{T}$ cell) are considered immunogenic. The sequences of herpes simplex viral proteins that align with beta-amyloid are shown. Space: non-identical amino acid; +: conserved amino acid with similar physicochemical properties. Viruses and phages containing the VGGVV sequence, which has been used as an epitope to label beta-amyloid in Alzheimer's disease, are also shown.

performance [52]. However amyloid antibodies extracted from the serum of old APP transgenic mice potentiate the toxicity of beta-amyloid, and Alzheimer's disease patients display an enhanced immune response to the peptide [53]. Again in transgenic mice, different immune backgrounds can influence the type of immune responses elicited by betaamyloid. For example, $B$ and $T$ cell responses to beta-amyloid can be modified in HLA-DR3, -DR4, -DQ6, or -DQ8 transgenic mice [54]. HLA-antigen diversity in Man is also likely to determine the outcome of beta-amyloid/antibody interactions. A large number of Alzheimer's disease susceptibility gene candidates, including clusterin and complement receptor 1 , as well as diverse interleukins and other cytokines, C reactive protein, HLA-antigens, Fc epsilon and Toll receptors, and the viral-activated kinase PKR, are intimately concerned with pathogen defence and or the immune system, supporting a genetic contribution to the immune pathogenesis of Alzheimer's disease (see http:// www.polygenicpathways.co.uk/alzpolys.html.)

Beta-amyloid vaccination in Alzheimer's disease (against Abeta $_{1-42}$ ) has so far not been successful and sadly resulted in meningoencephalitis and the death of a patient [55]. While certain beta-amyloid antibodies may reduce plaque burden, there is an evident risk that they may also trigger an autoimmune response, potentially killing beta-amyloid containing neurones. Catalytic autoantibodies are less able 


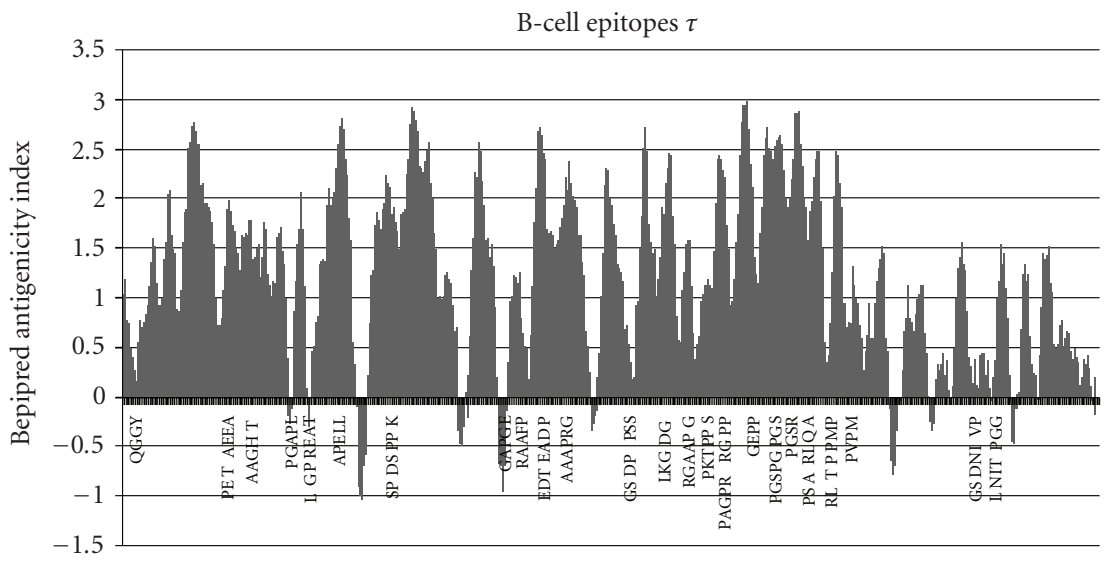

(a)

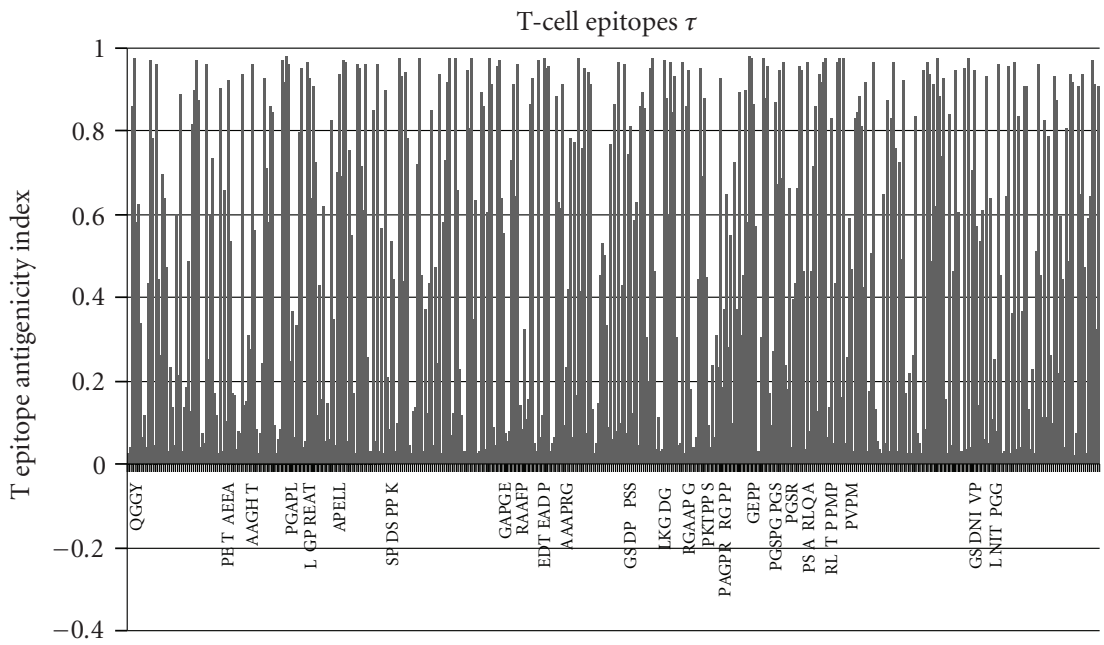

(b)

FIgURE 3: The B cell and T cell immunogenicity profile for the tau protein. The sequences of herpes simplex viral proteins that align with tau are shown. Space: non-identical amino acid; +: conserved amino acid with similar physicochemical properties.

to form stable immune complexes and likely represent the safest way forward in this area [56,57]. Given the homology of beta-amyloid to so many viruses and the potential dangers of autoimmunity, as well as the clearly toxic effects of tau immunisation, the pursuit of clinical trials with beta-amyloid antibodies, with the exception of catalytic forms, must surely be questioned.

\section{Conclusions}

Alzheimer's disease proteins encoded by all of the major genetic players in Alzheimer's disease and many other relevant proteins are homologous to proteins from the herpes simplex virus, confirming the implication of this virus as a causative agent in this disease [48, 50, 5870]. Because of homology to other viruses and pathogens, these too may be implicated. These include HHV-6, the cytomegalovirus, Borrelia, Burgdorferi, Chlamydia Pneumoniae, Helicobacter pylori, Cryptococcus neoformans and bacteria promoting gum disease, such as P. Gingivalis, all of which also express proteins homologous to the products of numerous Alzheimer's disease susceptibility genes (see http://www.polygenicpathways.co.uk/Alzheimer.htm).

No vaccine against HSV-1 exists, but in the long term, may perhaps be able to prevent Alzheimer's disease, although the potential dangers of vaccine-related autoimmunity evidently need to be addressed. Interestingly, cancer-causing viruses including the Epstein-Barr-virus, hepatitis b, and the papillomavirus align with the peptide stretch within beta-amyloid [32] that is cleaved by the beneficial catalytic autoantibodies to beta-amyloid [56,57]. Cancer is inversely associated with the risk of developing Alzheimer's disease $[71,72]$. As a vaccine to the human papillomavirus already exists to prevent cervical cancer [73], it may well have a role to play in the prevention or therapy of Alzheimer's disease, again with due regard to the problem of vaccinerelated autoimmunity. Alternatively, immunisation with this beneficial region of the beta-amyloid peptide might be considered as a viable therapeutic option.

Many of the toxic effects of HSV-1 infection are likely to be related to autoimmunity, caused by antibodies to the viral proteins that also target their human counterparts. In this case, it is possible that immunosuppressant therapy 
may be of benefit in Alzheimer's disease patients and also that aggressive antiviral therapy should be pursued. Immunoadsorption of tau and beta-amyloid antibodies, a technique used to good effect in certain patients with myasthenia gravis (characterised by autoantibodies to nicotinic receptors) [74] may also be of benefit. As other pathogens may also demonstrate this type of mimicry, detailed and regular pathogen screens in the ageing population and in the early stages of Alzheimer's patients may also be of use.

Alzheimer's disease thus appears to be one, probably of many, "pathogenetic" diseases, caused by viruses and other pathogens, but dependent on our genes, which dictate the protein sequences that match those in particular subsets of pathogen proteins. There are almost 3,000 viral genomes in the NCBI database, probably reflecting but a small proportion of those existing on the planet. In addition, as viruses regularly mutate with replication there are likely to be multiple strains of HSV-1 (and other viruses), only one of which is recorded in the NCBI database. Nevertheless, with current bioinformatics techniques, it should be possible to rapidly identify all vatches in the human proteome, to match them to particular viruses (and other pathogens, Bacteria, fungi, yeast, parasites, etc.), and to pair these with diverse human diseases. Our understanding of this universal phenomenon could radically change the face of therapy in a variety of human conditions.

\section{References}

[1] R. F. Itzhaki, C. B. Dobson, W.-R. Lin, and M. A. Wozniak, "Association of HSV1 and apolipoprotein E- $\varepsilon 4$ in Alzheimer's disease," Journal of NeuroVirology, vol. 7, no. 6, pp. 570-571, 2001.

[2] R. F. Itzhaki, C. B. Dobson, M. A. Wozniak et al., "Herpes simplex virus type 1 and Alzheimer's disease," Annals of Neurology, vol. 55, no. 2, pp. 299-301, 2004.

[3] R. F. Itzhaki and M. A. Wozniak, "Alzheimer's disease-like changes in herpes simplex virus type 1 infected cells: the case for antiviral therapy," Rejuvenation Research, vol. 11, no. 2, pp. 319-320, 2008.

[4] M. A. Wozniak, R. F. Itzhaki, S. J. Shipley, and C. B. Dobson, "Herpes simplex virus infection causes cellular $\beta$-amyloid accumulation and secretase upregulation," Neuroscience Letters, vol. 429, no. 2-3, pp. 95-100, 2007.

[5] M. A. Wozniak, A. L. Frost, and R. F. Itzhaki, "Alzheimer's disease-specific tau phosphorylation is induced by herpes simplex virus type 1," Journal of Alzheimer's Disease, vol. 16, no. 2, pp. 341-350, 2009.

[6] A. G. Armien, S. Hu, M. R. Little et al., "Chronic cortical and subcortical pathology with associated neurological deficits ensuing experimental herpes encephalitis," Brain Pathology, vol. 20, no. 4, pp. 738-750, 2010.

[7] L. Letenneur, K. Pérès, H. Fleury et al., "Seropositivity to herpes simplex virus antibodies and risk of Alzheimer's disease: a population-based cohort study," PLOS ONE, vol. 3, no. 11, Article ID e3637, 2008.

[8] S. F. Altschul, T. L. Madden, A. A. Schäffer et al., "Gapped BLAST and PSI-BLAST: a new generation of protein database search programs," Nucleic Acids Research, vol. 25, no. 17, pp. 3389-3402, 1997.
[9] J. E. Larsen, O. Lund, and M. Nielsen, "Improved method for predicting linear B-cell epitopes," Immunome Research, vol. 2, article 2, 2006.

[10] M. Nielsen, C. Lundegaard, O. Lund, and C. Keşmir, "The role of the proteasome in generating cytotoxic T-cell epitopes: insights obtained from improved predictions of proteasomal cleavage," Immunogenetics, vol. 57, no. 1-2, pp. 33-41, 2005.

[11] C. J. Carter, "Herpes simplex: host viral protein interactions," WikiGenes. In press.

[12] H. P. Huemer, Y. Wang, P. Garred, V. Koistinen, and S. Oppermann, "Herpes simplex virus glycoprotein C: molecular mimicry of complement regulatory proteins by a viral protein," Immunology, vol. 79, no. 4, pp. 639-647, 1993.

[13] R. Tal-Singer, C. Seidel-Dugan, L. Fries et al., "Herpes simplex virus glycoprotein $\mathrm{C}$ is a receptor for complement component iC3b," Journal of Infectious Diseases, vol. 164, no. 4, pp. 750753, 1991.

[14] C. J. Carter, "Convergence of genes implicated in Alzheimer's disease on the cerebral cholesterol shuttle: APP, cholesterol, lipoproteins, and atherosclerosis," Neurochemistry International, vol. 50, no. 1, pp. 12-38, 2007.

[15] S. Jaeger and C. U. Pietrzik, "Functional role of lipoprotein receptors in Alzheimer's disease," Current Alzheimer Research, vol. 5, no. 1, pp. 15-25, 2008.

[16] I. J. Martins, T. Berger, M. J. Sharman, G. Verdile, S. J. Fuller, and R. N. Martins, "Cholesterol metabolism and transport in the pathogenesis of Alzheimer's disease," Journal of Neurochemistry, vol. 111, no. 6, pp. 1275-1308, 2009.

[17] A. Papassotiropoulos, M. A. Wollmer, M. Tsolaki et al., "A cluster of cholesterol-related genes confers susceptibility for Alzheimer's disease," Journal of Clinical Psychiatry, vol. 66, no. 7, pp. 940-947, 2005.

[18] G. Campadelli-Fiume, P. Mirandola, and L. Menotti, "Human herpesvirus 6: an emerging pathogen," Emerging Infectious Diseases, vol. 5, no. 3, pp. 353-366, 1999.

[19] C. J. Hammond, L. R. Hallock, R. J. Howanski, D. M. Appelt, C. S. Little, and B. J. Balin, "Immunohistological detection of Chlamydia pneumoniae in the Alzheimer's disease brain," BMC Neuroscience, vol. 11, article 121, 2010.

[20] P. S. Stein, M. Desrosiers, S. J. Donegan, J. F. Yepes, and R. J. Kryscio, "Tooth loss, dementia and neuropathology in the Nun Study," Journal of the American Dental Association, vol. 138, no. 10, pp. 1314-1322, 2007.

[21] J. Miklossy, K. Khalili, L. Gern et al., "Borrelia burgdorferi persists in the brain in chronic lyme neuroborreliosis and may be associated with Alzheimer disease," Journal of Alzheimer's Disease, vol. 6, no. 6, pp. 639-649, 2004.

[22] W. R. Lin, M. A. Wozniak, R. J. Cooper, J. K. Wilcock, and R. F. Itzhaki, "Herpesviruses in brain and Alzheimer's disease," Journal of Pathology, vol. 197, no. 3, pp. 395-402, 2002.

[23] T. A. Ala, R. C. Doss, and C. J. Sullivan, "Reversible dementia: a case of cryptococcal meningitis masquerading as Alzheimer's disease," Journal of Alzheimer's Disease, vol. 6, no. 5, pp. 503508, 2004.

[24] M. Hoffmann, J. Muniz, E. Carroll, and J. De Villasante, "Cryptococcal meningitis misdiagnosed as alzheimer's disease: complete neurological and cognitive recovery with treatment," Journal of Alzheimer's Disease, vol. 16, no. 3, pp. 517-520, 2009.

[25] J. Kountouras, M. Boziki, E. Gavalas et al., "Eradication of Helicobacter pylori may be beneficial in the management of Alzheimer's disease," Journal of Neurology, vol. 256, no. 5, pp. 758-767, 2009. 
[26] C. J Carter, "Proteins of the XMRV retrovirus implicated in chronic fatigue syndrome and prostate cancer are homologous to human proteins relevant to both diseases," Nature Precedings. In press.

[27] C. J. Carter, "Extensive Viral mimicry of human proteins in AIDS, autoimmune disorders, late-onset and familial Alzheimer;s disease and other genetic diseases," Nature Precedings. In press.

[28] C. Schwab, H. Akiyama, E. G. McGeer, and P. L. McGeer, "Extracellular neurofibrillary tangles are immunopositive for the 40 carboxy-terminal sequence of $\beta$-amyloid protein," Journal of Neuropathology and Experimental Neurology, vol. 57, no. 12, pp. 1131-1137, 1998.

[29] J. B. S. Haldane, "The origin of life," Rationalist Annual, vol. 148, pp. 3-10, 1988.

[30] F. D'Herelle, The Bacteriophage; Its Role in Immunity, Masson et Cie, Paris, France, 1922.

[31] K. Khodosevich, Y. Lebedev, and E. Sverdlov, "Endogenous retroviruses and human evolution," Comparative and Functional Genomics, vol. 3, no. 6, pp. 494-498, 2002.

[32] C. J. Carter, "Familial and late-onset Alzheimer's disease: autoimmune disorders triggered by viral, microbial and allergen mimics of beta-amyloid and APP mutants ?" Nature Precedings. In press.

[33] C. J. Carter, "The human genome is composed of viral DNA: Viral homologues of the protein products cause Alzheimer's disease and others via autoimmune mechanisms," Nature Precedings. In press.

[34] G. R. Seabrook and T. W. Rosahl, "Transgenic animals relevant to Alzheimer's disease," Neuropharmacology, vol. 38, no. 1, pp. 1-17, 1999.

[35] Y. Senechal, P. H. Kelly, J. F. Cryan, F. Natt, and K. K. Dev, "Amyloid precursor protein knockdown by siRNA impairs spontaneous alternation in adult mice," Journal of Neurochemistry, vol. 102, no. 6, pp. 1928-1940, 2007.

[36] T. L. Spires and B. T. Hyman, "Transgenic models of Alzheimer's disease: learning from animals," NeuroRx, vol. 2, no. 3, pp. 423-437, 2005.

[37] D.-L. Zhang, Y.-Q. Chen, X. Jiang, T.-T. Ji, and B. Mei, “Oxidative damage increased in presenilin1/presenilin2 conditional double knockout mice," Neuroscience Bulletin, vol. 25, no. 3, pp. 131-137, 2009.

[38] M. Hiltunen, T. Van Groen, and J. Jolkkonen, "Functional roles of amyloid- $\beta$ protein precursor and amyloid- $\beta$ peptides: evidence from experimental studies," Journal of Alzheimer's Disease, vol. 18, no. 2, pp. 401-412, 2009.

[39] D. Langui, F. Lachapelle, and C. Duyckaerts, "Animal models of neurodegenerative diseases," Medecine/Sciences, vol. 23, no. 2, pp. 180-186, 2007.

[40] P. Eikelenboom, E. Van Exel, J. J.M. Hoozemans, R. Veerhuis, A. J.M. Rozemuller, and W. A. Van Gool, "Neuroinflammation-an early event in both the history and pathogenesis of Alzheimer's disease," Neurodegenerative Diseases, vol. 7, no. 1-3, pp. 38-41, 2010.

[41] R. Veerhuis, I. Janssen, C. E. Hack, and P. Eikelenboom, "Early complement components in Alzheimer's disease brains," Acta Neuropathologica, vol. 91, no. 1, pp. 53-60, 1996.

[42] R. Veerhuis, I. Janssen, C. J. A. De Groot, F. L. Van Muiswinkel, C. E. Hack, and P. Eikelenboom, "Cytokines associated with amyloid plaques in Alzheimer's disease brain stimulate human glial and neuronal cell cultures to secrete early complement proteins, but not C1-inhibitor," Experimental Neurology, vol. 160, no. 1, pp. 289-299, 1999.
[43] M. R. D’Andrea, "Evidence linking neuronal cell death to autoimmunity in Alzheimer's disease," Brain Research, vol. 982, no. 1, pp. 19-30, 2003.

[44] R. Veerhuis, P. Van der Valk, I. Janssen, S. S. Zhan, W. E. Van Nostrand, and P. Eikelenboom, "Complement activation in amyloid plaques in Alzheimer's disease brains does not proceed further than C3," Virchows Archiv, vol. 426, no. 6, pp. 603-610, 1995.

[45] P. L. McGeer, H. Akiyama, S. Itagaki, and E. G. McGeer, "Activation of the classical complement pathway in brain tissue of Alzheimer patients," Neuroscience Letters, vol. 107, no. 1-3, pp. 341-346, 1989.

[46] S. Itagaki, H. Akiyama, H. Saito, and P. L. McGeer, "Ultrastructural localization of complement membrane attack complex (MAC)-like immunoreactivity in brains of patients with Alzheimer's disease," Brain Research, vol. 645, no. 1-2, pp. 78 84, 1994

[47] H. Zanjani, C. E. Finch, C. Kemper et al., "Complement activation in very early Alzheimer disease," Alzheimer Disease and Associated Disorders, vol. 19, no. 2, pp. 55-66, 2005.

[48] H. Rosenmann, N. Grigoriadis, D. Karussis et al., "Tauopathylike abnormalities and neurologic deficits in mice immunized with neuronal tau protein," Archives of Neurology, vol. 63, no. 10, pp. 1459-1467, 2006.

[49] M. A. C. Morelli, M. DeBiasi, A. DeStradis, and A. M. Tamburro, "An aggregating elastin-like pentapeptide," Journal of Biomolecular Structure and Dynamics, vol. 11, no. 1, pp. 181-190, 1993.

[50] D. H. Cribbs, B. Y. Azizeh, C. W. Cotman, and F. M. LaFerla, "Fibril formation and neurotoxicity by a herpes simplex virus glycoprotein B fragment with homology to the Alzheimer's A $\beta$ peptide," Biochemistry, vol. 39, no. 20, pp. 5988-5994, 2000.

[51] D. Schenk, R. Barbour, W. Dunn et al., "Immunization with amyloid- $\beta$ attenuates Alzheimer disease-like pathology in the PDAPP mouse," Nature, vol. 400, no. 6740, pp. 173-177, 1999.

[52] S. Röskam, F. Neff, R. Schwarting, M. Bacher, and R. Dodel, "APP transgenic mice: the effect of active and passive immunotherapy in cognitive tasks," Neuroscience and Biobehavioral Reviews, vol. 34, pp. 487-499, 2010.

[53] A. Nath, E. Hall, M. Tuzova et al., "Autoantibodies to amyloid $\beta$-peptide $(\mathrm{A} \beta)$ are increased in Alzheimer's disease patients and $\mathrm{A} \beta$ antibodies can enhance $\mathrm{A} \beta$ neurotoxicity: implications for disease pathogenesis and vaccine development," NeuroMolecular Medicine, vol. 3, no. 1, pp. 29-39, 2003.

[54] P. Das, S. Chapoval, V. Howard, C. S. David, and T. E. Golde, "Immune responses against $\mathrm{A} \beta 1-42$ in HLA class II transgenic mice: implications for A $\beta 1-42$ immune-mediated therapies," Neurobiology of Aging, vol. 24, no. 7, pp. 969-976, 2003.

[55] I. Ferrer, M. Boada Rovira, M. L. Sánchez Guerra, M. J. Rey, and F. Costa-Jussá, "Neuropathology and pathogenesis of encephalitis following amyloid- $\beta$ immunization in Alzheimer's disease," Brain Pathology, vol. 14, no. 1, pp. 11-20, 2004.

[56] S. Paul, S. Planque, and Y. Nishiyama, "Immunological origin and functional properties of catalytic autoantibodies to amyloid $\beta$ peptide," Journal of Clinical Immunology, vol. 30, supplement 1, pp. S43-S49, 2010.

[57] H. Taguchi, S. Planque, G. Sapparapu et al., "Exceptional amyloid $\beta$ peptide hydrolyzing activity of nonphysiological immunoglobulin variable domain scaffolds," Journal of Biological Chemistry, vol. 283, no. 52, pp. 36724-36733, 2008. 
[58] J. S. Burgos, C. Ramirez, I. Sastre, and F. Valdivieso, "Effect of apolipoprotein $\mathrm{E}$ on the cerebral load of latent herpes simplex virus type 1 DNA," Journal of Virology, vol. 80, no. 11, pp. 5383-5387, 2006.

[59] C. J. Carter, "Interactions between the products of the Herpes simplex genome and Alzheimer's disease susceptibility genes: relevance to pathological-signalling cascades," Neurochemistry International, vol. 52, no. 6, pp. 920-934, 2008.

[60] K. Honjo, R. van Reekum, and N. P. L. G. Verhoeff, "Alzheimer's disease and infection: do infectious agents contribute to progression of Alzheimer's disease?" Alzheimer's and Dementia, vol. 5, no. 4, pp. 348-360, 2009.

[61] R. Itzhaki, "Herpes simplex virus type 1, apolipoprotein E and alzheimer's disease," Herpes, vol. 11, supplement 2, pp. 77A82A, 2004.

[62] R. F. Itzhaki, W.-R. Lin, D. Shang, G. K. Wilcock, B. Faragher, and G. A. Jamieson, "Herpes simplex virus type 1 in brain and risk of Alzheimer's disease," Lancet, vol. 349, no. 9047, pp. 241-244, 1997.

[63] R. F. Itzhaki, M. A. Wozniak, D. M. Appelt, and B. J. Balin, "Infiltration of the brain by pathogens causes Alzheimer's disease," Neurobiology of Aging, vol. 25, no. 5, pp. 619-627, 2004.

[64] I. Kuhlmann, A. M. Minihane, P. Huebbe, A. Nebel, and G. Rimbach, "Apolipoprotein e genotype and hepatitis C, HIV and herpes simplex disease risk: a literature review," Lipids in Health and Disease, vol. 9, article 8, 2010.

[65] W.-R. Lin, D. Shang, and R. F. Itzhaki, "Neurotropic viruses and Alzheimer disease: interaction of herpes simplex type I virus and apolipoprotein E in the etiology of the disease," Molecular and Chemical Neuropathology, vol. 28, no. 1-3, pp. 135-141, 1996.

[66] R. B. Pyles, "The association of herpes simplex virus and Alzheimer's disease: a potential synthesis of genetic and environmental factors," Herpes, vol. 8, no. 3, pp. 64-68, 2001.

[67] M. A. Wozniak, S. J. Shipley, M. Combrinck, G. K. Wilcock, and R. F. Itzhaki, "Productive herpes simplex virus in brain of elderly normal subjects and Alzheimer's disease patients," Journal of Medical Virology, vol. 75, no. 2, pp. 300-306, 2005.

[68] R. F. Itzhaki and M. A. Wozniak, "Herpes simplex virus type 1 in Alzheimer's disease: the enemy within," Journal of Alzheimer's Disease, vol. 13, no. 4, pp. 393-405, 2008.

[69] I. Mori, Y. Kimura, H. Naiki et al., "Reactivation of HSV-1 in the brain of patients with familial Alzheimer's disease," Journal of Medical Virology, vol. 73, no. 4, pp. 605-611, 2004.

[70] Á. Zambrano, L. Solis, N. Salvadores, M. Cortés, R. Lerchundi, and C. Otth, "Neuronal cytoskeletal dynamic modification and neurodegeneration induced by infection with herpes simplex virus type 1," Journal of Alzheimer's Disease, vol. 14, no. 3, pp. 259-269, 2008.

[71] C. M. Roe, M. I. Behrens, C. Xiong, J. P. Miller, and J. C. Morris, "Alzheimer disease and cancer," Neurology, vol. 64, no. 5, pp. 895-898, 2005.

[72] C. M. Roe, A. L. Fitzpatrick, C. Xiong et al., "Cancer linked to Alzheimer disease but not vascular dementia," Neurology, vol. 74, no. 2, pp. 106-112, 2010.

[73] S. M. Garland and J. S. Smith, "Human papillomavirus vaccines: current status and future prospects," Drugs, vol. 70, no. 9, pp. 1079-1098, 2010.

[74] S. Wagner, R. W.C. Janzen, C. Mohs, S. Pohlmann, R. Klingel, and P. W. Grützmacher, "Long-term treatment of refractory myasthenia gravis with immunoadsorption Langzeitbehandlung der therapierefraktären myasthenia gravis mittels immunadsorption," Deutsche Medizinische Wochenschrift, vol. 133, no. 46, pp. 2377-2382, 2008. 


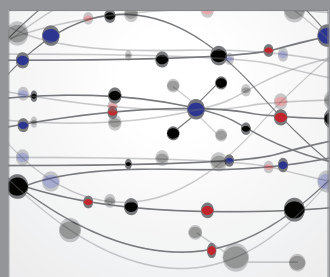

The Scientific World Journal
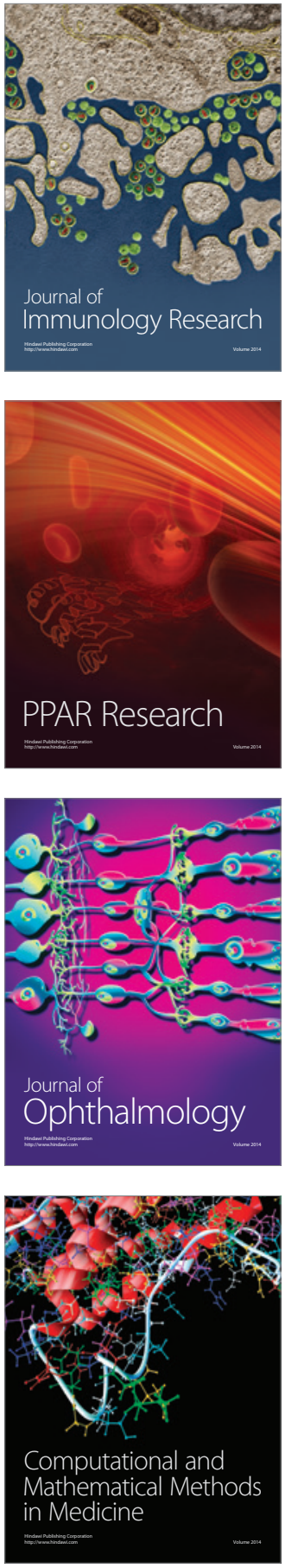

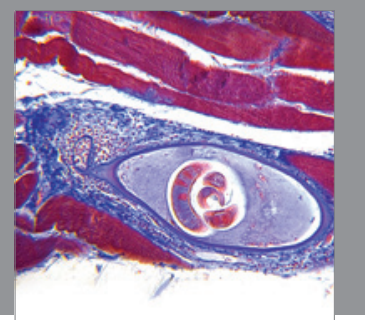

Gastroenterology

Research and Practice
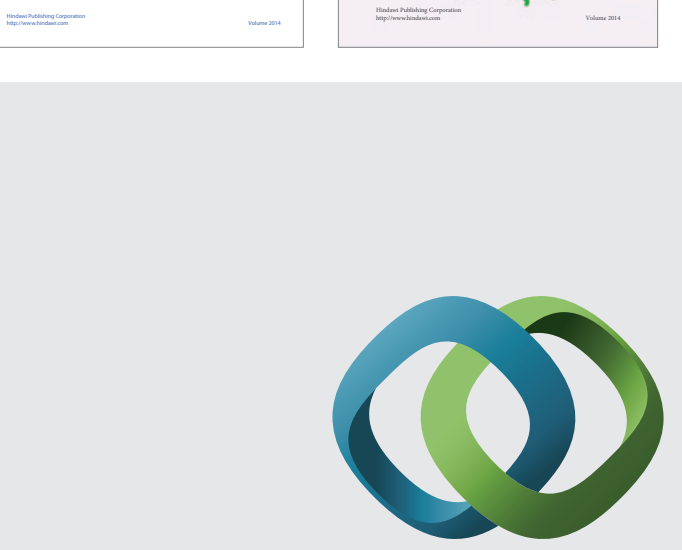

\section{Hindawi}

Submit your manuscripts at

http://www.hindawi.com
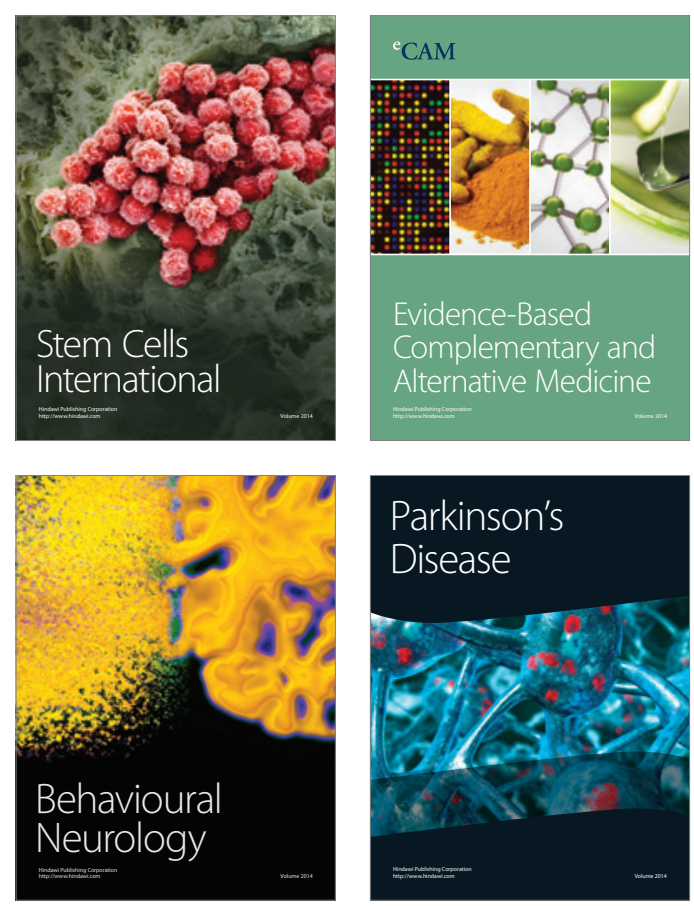

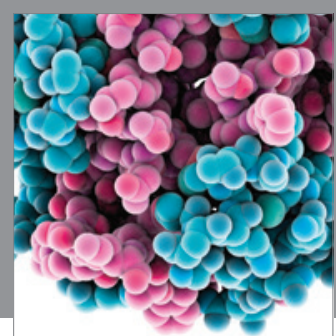

Journal of
Diabetes Research

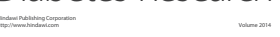

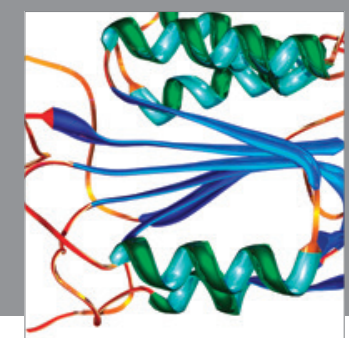

Disease Markers
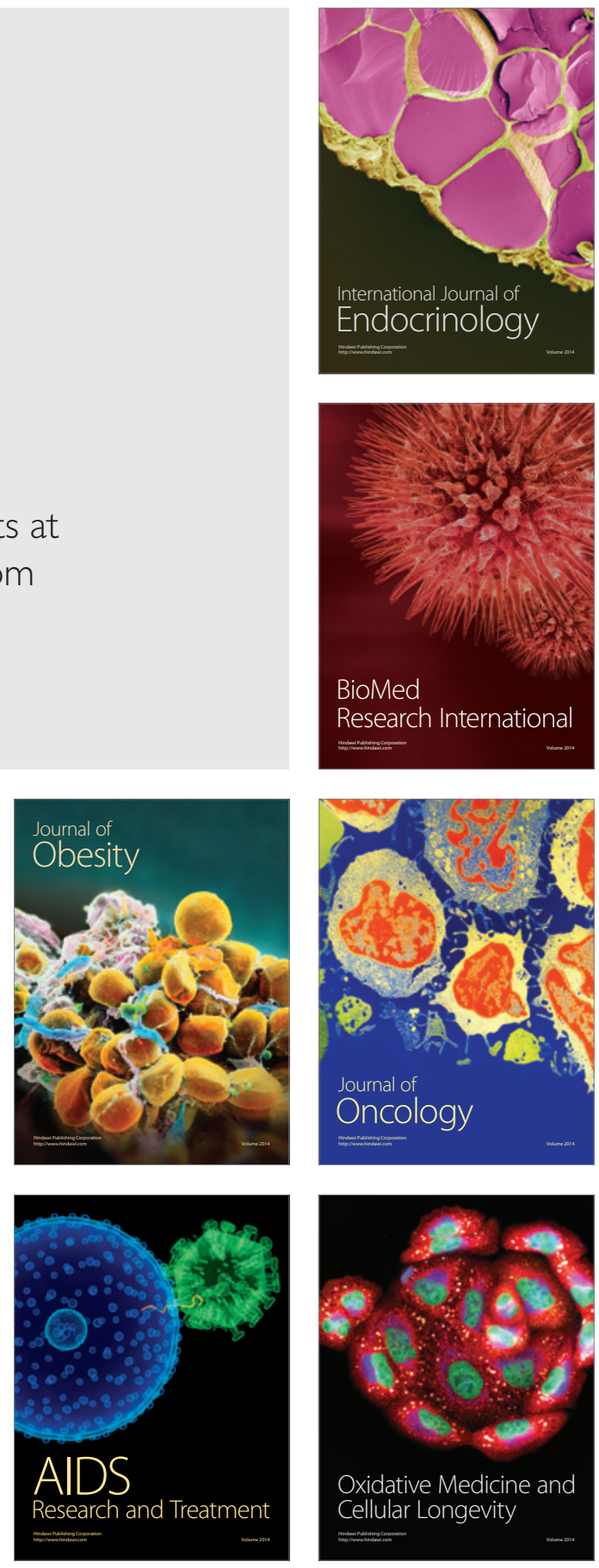